\title{
Huntington Hastalığı'nın Nöropsikiyatrik Yönü
} Neuropsychiatric Aspects of Huntington's Disease

\author{
๑ Özlem Devrim Balaban¹, ๑ E. Cem Atbaşoğlu²
}

1Sağlık Bilimleri Üniversitesi, İstanbul, Türkiye

2Ankara Üniversitesi, Ankara, Türkiye

Huntington Hastalığı; kore ve distoni, koordinasyon bozukluğu, bilişsel performansta bozulmalar ve davranışsal sorunlar gibi farklı fenotipler ile ortaya çıkabilen, genetik olarak otozomal dominant geçiş özelliğine sahip, ilerleyici tipte bir nörodejeneratif hastalıktır. Bilişsel ve motor belirtilerin yanı sıra nöropsikiyatrik belirtiler de hastalığın çekirdek belirtileri arasında yer almaktadır. Huntington Hastalığı'nda nöropsikiyatrik belirtiler oldukça sık görülmekte ve hastalığın farklı dönemlerinde psikiyatrik bozuklukların görülme prevelansı \%33-76 olarak tahmin edilmektedir. Nöropsikiyatrik belirtilerin görülme sıklığı hastalığın evrelerine göre farklılık gösterse de başlangıcının motor belirtiler başlamadan yıllar önce olabileceği de bilinmektedir. Huntington Hastalığı'nda sık görülen nöropsikiyatrik belirti ve bozukluklar depresyon, anksiyete, intihar, irritabilite, apati, obsesif-kompulsif belirtiler, perseverasyonlar, psikoz, uyku bozuklukları ve cinsel işlev bozuklukları olarak sayılabilir. Nöropsikiyatrik belirtiler aileler üzerindeki yükün en önemli nedenlerinden birini oluşturmakta, günlük işlevsellikteki azalma ile bakım kurumlarına yerleştirilme ve hastaneye yatışların en önemli öngörücüsü olarak değerlendirilmektedir. Hem sıklığı hem de sonuçları göz önüne alındığında Huntington Hastalığı'ndaki nöropsikiyatrik belirtilerin tanınması ve bu belirtilere müdahale edilmesi hastalar, hasta yakınları ve bakımverenleri için oldukça önemlidir. Hastalıkta görülen nöropsikiyatrik belirtilerin tedavisi ile ilgili yüksek kanıt düzeyine sahip araştırmalar olmasa da daha düşük kanıt düzeyine sahip çalışmalar, vaka bildirimleri ve uzman görüşlerine dayalı tedavi kılavuzları son yıllarda yazında kendine yer bulmuştur. Bu alanda dikkat edilmesi gereken başka bir konu da risk altındaki bireylerin değerlendirilmesi, genetik danışmanlık ve bu değerlendirmeler sırasında güvenli bir protokolün oluşturulmasıdır. Bu yazıda Huntington Hastalığı’nda sık görülen nöropsikiyatrik bozukluklar, bu bozuklukların tedavisi ve risk altındaki bireyleri değerlendirmede dikkat edilmesi gereken durumlar güncel yazın ışı̆̆ında derlenmiştir.

Anahtar sözcükler: Huntington Hastalığı, nöropsikiyatrik bozukluk, tedavi, genetik risk

Huntington's Disease is a progressive neurodegenerative disorder inherited in an autosomal dominant fashion with distinct phenotypes as chorea and dystonia, incoordination, cognitive disorders, and behavioural problems. In addition to cognitive and motor symptoms, neuropsychiatric symptoms are among the core symptoms of the disease. Neuropsychiatric symptoms are quite common in Huntington's Disease and the prevalence of neuropsychiatric disorders in different stages of the disease is estimated to be 33-76\%. Although the prevelance of neuropsychiatric symptoms varies among the stages of the disease, it is also known that the onset of these symptoms may be years before the onset of motor symptoms. Common neuropsychiatric symptoms and disorders in Huntington's Disease include depression, anxiety, suicide, irritability, apathy, obsessive-compulsive symptoms, perseverations, psychosis, sleep disorders, and sexual dysfunctions. Neuropsychiatric symptoms constitute one of the most important factors for the burden on families, and are considered to be the most important predictors of decrease in daily functionality and institutionalizations in care centers and hospitalizations. Considering both its frequency and outcomes, it is very important for patients, their relatives and caregivers to recognize and intervene in neuropsychiatric symptoms of Huntington's Disease. Although there are no studies with a high level of evidence on the treatment of neuropsychiatric symptoms of the disease, studies with lower levels of evidence, case reports and treatment guidelines based on expert opinions are found in the literature in recent years. Another issue to be considered in this area is the evaluation of individuals at genetic risk, genetic counseling and setting a safe protocol during these evaluations. In this article, neuropsychiatric disorders common in Huntington's Disease, the management of these disorders and the conditions to be considered in the evaluation of individuals at genetic risk are reviewed in the light of current literature.

Keywords: Huntington's Disease, neuropsychiatric disorder, treatment, genetic risk

Yazışma Adresi/Address for Correspondence: Özlem Devrim Balaban, Sağlık Bilimleri Üniversitesi, Bakırköy Prof. Dr. Mazhar Osman Ruh Sağlığı ve Sinir Hastalıkları Eğitim ve Araştırma Hastanesi, Psikiyatri Kliniği, İstanbul, Türkiye

E-posta/E-mail: ozlemdevrimbalaban@gmail.com Geliş tarihi/Received: 16.06.2021 Kabul tarihi/Accepted: 23.08.2021

ORCID ID: 0000-0001-7903-549X 


\section{Giriş}

Huntington Hastalığı (HH); kore ve distoni, koordinasyon bozukluğu, bilişsel performansta bozulmalar ve davranışsal sorunlar gibi farklı fenotipler ile ortaya çıkabilen, genetik olarak otozomal dominant geçiş özelliğine sahip, ilerleyici tipte bir nörodejeneratif hastalıktır (Walker 2007). HH ile ilişkili gen, huntingtin (HTT), yaklaşık üç dekad önce keşfedilmiş, o zamandan beri hastalığın patogenezini ve nörobiyolojisini anlamada çok yol kat edilmiştir. HH'nin nedeni, 4. kromozomun kısa kolunda bulunan ve HTT proteininin yapısındaki poliglutamini kodlayan CAG trinükleotid tekrarında genişleme (expansion) olarak bildirilmektedir (Ross ve Tabrizi 2011). Bu trinükleotid tekrarı 36 ve üzerinde olursa patolojik olarak kabul edilmekte ve beyinde yaygın olarak bulunan ancak henüz işlevi tam olarak anlaşılamamış poliglutaminin anormal sentezi ile sonuçlanmaktadır (Anderson 2005). HHW'deki nöropatolojik değişimler belirgin olarak seçicilik göstermekte; hastalık, kaudat ve putamende öne çıkan hücre kaybı ve atrofi ile başlamaktadır (Craufurd ve Snowden 2002). Hastalığın erken evrelerinde nörodejenerasyon çok ön planda olmasa da, asemptomatik dönemde dahi belirgin nöronal işlev bozukluğu olduğuna dair tutarlı kanıtlar bulunmaktadır. İlerleyen dönemlerinde ise hastalığın santral sinir sistemini yaygın olarak etkileyen bir nörodejenerasyona yol açtığı bilinmektedir (Walker 2007).

HH'li çoğu olguda başlama yaşı 35 ile 45 arasında olup ortalama hastalık süresi 16 yıldır. Hastalık, bağımsız yaşam becerilerinin azalması ve motor/bilişsel işlevlerde bozulma ve psikiyatrik belirtilerin varlığına bağlı olarak yaşamı sürdürmeye ilişkin duyulan yardım ihtiyacına göre bazı evrelere (premanifest/ presemptomatik, hafif belirtiler, fenodönüşüm/fenokonversiyon ve manifest/semptomatik) ayrılarak tanımlanmaktadır (Sinanović 2020). Semptomatik olguların prevelansı yaklaşık olarak 10/100.000 olarak bildirilmekte olsa da sosyal damgalanma ve her ülke ya da birimde genetik test yapma olanağının olmaması nedeniyle aslında daha yaygın olabileceği düşünülmektedir (Rawlins 2010). Hh'nin kesin tanısı genetik test ile konuluyor olsa da bazen nörogörüntüleme çalışmaları da yol gösterici olabilmektedir. Yapısal beyin görüntüleme tetkiklerinde striatal hacim kaybı ve lateral ventriküllerin frontal boynuzunda hacim artması HH'yi destekleyen bulgular olmakla beraber hastalığın erken evrelerinde bu bulguların saptanamayabileceğinin de altını çizmek gerekir. Ancak fonksiyonel nörogörüntüleme teknikleri ile belirtiler başlamadan önce de lateral prefrontal ve singulat bölgelerde işlev bozukluğu gibi beyin işlev bozuklukları gösterilebilmektedir (Stober ve ark. 1984, Wolf ve ark. 2008, Paulsen 2009).

HH'nin klinik olarak tanısı motor semptomların varlığına dayalı olsa da bilişsel işlev bozuklukları ve psikiyatrik belirtiler aileler üzerindeki yükün en önemli nedenlerini oluşturmakta, günlük işlevsellikteki azalma ile bakım kurumlarına yerleştirilme ve hastaneye yatışların en önemli öngörücüsü olarak değerlendirilmektedir (Ross ve ark. 2014, Ishihara ve ark. 2021). Üstelik depresyon, apati ve irritabilite gibi nöropsikiyatrik belirti ve bozukluklar motor belirtiler başlamadan yıllar önce ortaya çlkabilmektedir (van Duijn ve ark. 2007). Bu belirti ve bulguların etiyolojisi halen tam olarak açıklığa kavuşturulmamışsa da, nörodejeneratif sürecin -özellikle bazal ganglia-talamokortikal devreleri içeren- ilerleyici doğası, HH olan bireylerde nöropsikiyatrik belirtilerin sık görülmesinin altında yatan neden olarak görülmektedir (Martinez-Horta ve ark. 2016, van Duijn ve ark. 2007). HH olan bireylerin neredeyse hepsinin motor belirtilerden önce ya da sonra hipofrontal veya yürütücü işlev bozukluğu sendromu olarak da nitelendirilebilecek kişilik ve davranış değişiklikleri göstereceği bildirilmektedir. Apati, irritabilite, dürtüsellik ve obsesiflik olarak kabaca tanımlanabilecek bu belirti ve bulguların evlilik yaşamı, sosyal yaşam ve ekonomik süreçteki iyilik haline olumsuz etkileri olacağının altını çizmek gerekir (Ishihara ve ark. 2021, Nance ve ark. 2011).

Halen HH'deki dejeneratif süreci geri döndürecek ya da durduracak bir tedavisi seçeneği bulunmamaktadır ancak bu durum HH'deki nöropsikiyatrik belirti ve bozuklukların da tedavi edilemeyeceği şeklinde yanlış bir algıya neden olabilmektedir. Oysaki klinik deneyimler göstermiştir ki HH'yle ilişkili nöropsikiyatrik belirti ve bozuklukları hafifletecek tedavi seçenekleri bulunmakta, ağırlıklı olarak uzman görüşüne dayalı kılavuzlar ilgili yazında kendine yer bulmaktadır (Anderson ve ark. 2018).

$\mathrm{Bu}$ yazının amacı HH'de motor belirtiler öncesi ve sonrasında görülebilecek nöropsikiyatrik belirtilerin epidemiyolojisi, fenomenolojisi ve tedavisi ile ilgili yapılmış araştırmaları derlemek ve bu alanda çalışan klinisyenlere yol gösterecek bir metin oluşturmaktır. Bu amaçla öncelikle genel nöropsikiyatrik belirtilerden başlayarak apati, depresyon, irritabilite, dürtüsellik, anksiyete, intihar, obsesyonlar ve psikoz vb. olmak üzere alt başlıklar halinde sık görülen nöropsikiyatrik belirti ve bozukluklar ele alınacaktır.

\section{Huntington Hastalığında Görülen Nöropsikiyatrik Bozukluklar}

HH'nın tarihçesine bakıldığında ilk kez 1932'de John Eliotson tarafından herediter özellikte kore olgularının tarif edildiği, $\mathrm{HH}$ ile ilgili ilk yazılı metinin 1942'de Charles Waters tarafından kaleme alındığı bilinmektedir. 1872'de George Huntington tarafından belirtiler ve klinik gidişi tam olarak tarif edilen hastalık Huntington Koresi olarak adlandırılmış, ancak sonraki süreçlerde "sonunda intihara yol açan bir çeşit deliliğe yatkınlık" yaratan bir hastalık olduğu ifade edilerek motor belirtilere ek olarak HH'deki nöropsikiyatrik bulgulara dikkat çekilmiş, 1980'lerden sonra HH olarak yazında kendine yer bulmaya başlamıştır (Bhattacharyya 2016).

Hastalığın ilk tanımlanmaya başladığı yıllardan itibaren dikkat çeken davranışsal ve psikiyatrik belirti ve bulguların (prodromal belirtiler olarak da tanımlanırlar) sıklıkla motor belirtileri öncelediği; $\mathrm{HH}$ olan bireylerde, psikiyatrik bozuklukların yaşam boyu yaygınlığının \%33-76 gibi geniş bir aralıkta olduğu bildirilmektedir (van Duijn ve ark. 2007, Paoli ve ark. 2017, Sinanović 2020). Semptomatik ve presemptomatik (motor 
belirtiler başlamadan önce) dönemdeki hastaları değerlendiren kesitsel ve gözlemsel bir çalı̧̧mada HH olan olguların \%98'inde en az bir nöropsikiyatrik belirti olduğu saptanmıştır (Paulsen ve ark. 2001). Yakın tarihli bir araştırmada, üçüncü basamak bakım merkezine kayıtlı $144 \mathrm{HH}$ olgusu incelenmiş, olguların 17'sinin $(\% 11,8)$ kesitsel değerlendirme sırasında ölmüş olduğu, bu 17 ölümden 3'ünün intihar nedenli olduğu, yüz yüze değerlendirmeye alınabilen olguların ( $\mathrm{n}=81)$ \%91'inde psikiyatrik bir bozukluk saptandığı, \%21'inde de intihara eğilim olduğu bildirilmiştir (Ratna ve ark. 2020). Yaygınllk oranlarındaki farklllıklar çalışmalardaki metodolojik farklılıklardan (bazı çalışmalarda motor belirtiler açısından presemptomatik, bazılarında semptomatik, bazılarında ise karma gruplar değerlendirilmiştir) ve psikiyatrik bozuklukları değerlendirme ve saptamada farklı araçların (görüş̧meye dayalı değerlendirme, derecelendirme ölçeği ya da öz bildirim ölçekleri) kullanılmasından kaynaklanmaktadır (Paoli ve ark. 2017, Sinanović 2020). Klinik gidişat içerisinde bir psikiyatrik bozukluktan diğerine geçiş nadir olmasa da psikiyatrik değerlendirme ve tanılamada kullanılan katı tanısal kriterler, eşlik eden fiziksel belirtiler, bilişsel bozukluk ve iletişim problemleri nedeniyle hasta yakınlarından alınan bilgiler doğrultusunda tanılama yapılmaya çalışılması bu alandaki karıştırıcı faktörler olarak değerlendirilmektedir (Reedeker ve ark. 2012a).

HH'de nöropsikiyatrik bozuklukların sık görülmesi hastalığın ilerleyici nörodejenereratif özelliğine bağlanabilir ancak Ishihara ve arkadaşlarının (2021), retrospektif olarak yaptığı gözlemsel çalışmalarında birebir eşleştirilmiş $587 \mathrm{HH}$ ve Parkinson hastalığı $(\mathrm{PH})$ tanılı olgu ile nörodejeneratif bir hastalığı olmayan kontrol grubu kıyaslandığında, HH olan olguların hem PH olan olgular hem de kontrol grubundan birçok psikiyatrik belirti ve bozukluk açısından daha fazla risk altında olduğu ve $\mathrm{HH}$ olan olgularda antidepresan kullanma sıklığının ortalama \%59,9, antipsikotik kullanma sıklığının ise \%39.5 olduğu, bu sıklığın 50 yaş üzerinde olan olgularda daha da arttığı saptanmıştır. Bir ebeveyninde kesinleşmiş HH tanısı olan risk altındaki bireylerle yapılan bir çalışmada (n:254), katılımcılar 4 gruba ayrılmış, 1 . grubu $\mathrm{HH}$ için genetik riski olan ancak genetik analizde mutant gen taşıyıcısı olmadığı gösterilmiş (<32 CAG tekrarı) bireyler (n:171), 2. grubu $\geq 38$ CAG tekrari olan ancak motor belirtisi olmayan preklinik olgular (n:29), 3. grubu $\geq 38$ CAG tekrarı ve HH'ye atfedilebilecek motor belirtileri olan olgular (n:20), 4. grubu ise $\geq 38$ CAG tekrarı ve motor belirtileri kesin olarak $\mathrm{HH}$ ile ilişkili olan olgular (n:34) oluşturmuştur (Marshall ve ark. 2007). Bu çalışma; risk altındaki tüm olguların $\mathrm{HH}$ olan ebeveynin de olduğu benzer çevrede yetişmiş olması, yaş, cinsiyet, eğitim düzeyi gibi özellikler açısından grupların benzer olması ve değerlendirmeler sırasında araştırmacıların olguların genetik test sonuçlarına kör olunması açısından önemlidir. Marshall ve arkadaşları (2007) bu çalışmanın sonucunda diğer üç grupta 1. gruba kıyasla nöropsikiyatrik belirtilerin ve depresyonun anlamlı derecede daha fazla görüldügünü bildirmişlerdir. Bu çalışma, motor belirtiler başlamadan önce psikiyatrik belirtilerin başladığı ve bu belirtilerin aynı çevre ve koşullarda yetişseler bile mutant gen taşıyıcılarında daha sık görüldüğünü göstermesi ve HH'deki nöropsikiyatrik belirtilerin nörobiyolojik alt yapısına işaret etmesi açısından değerlidir. Erken evre $\mathrm{HH}$ olan hastalar ve aileleriyle yapılan kalitatif desenli bir çalışmada yarı yapılandırılmış görüşme araçları ile nöropsikiyatrik belirtilerin işlevsellik üzerine etkisi değerlendirilmiş, nöropsikiyatrik belirtilerin hem fiziksel, hem bilişsel hem de sosyal işlevsellik üzerine etkisi olduğu, günlük aktiviteleri olumsuz etkilediği ve sosyal içe çekilmeye neden olduğu, nöropsikiyatrik belirtilere müdahale etmenin işlevselliği düzelttiği bildirilmiştir (Gibson ve ark. 2022).

Hastalığın tarihçesine bakıldığında öncelikle motor belirtiler üzerinden bir tanımlamaya gidildiği, ardından bilişsel bozukluklardan sıklıkla bahsedildiği ancak sonrasında psikiyatrik belirtilerin fark edilip yazında kendine yer bulduğundan bahsedebiliriz. $\mathrm{Bu}$ açıdan bakıldığında nöropsikiyatrik bozuklukların HH'ye eşlik eden psikiyatrik belirtiler olarak değerlendirilmekten çok motor belirtiler gibi HH'nin çekirdek belirtileri olarak ele alınması gerekmektedir. Hastalığın tanılanması hatta genetik risk altındaki olguların değerlendirme aşamasından itibaren mümkünse nöroloji, psikiyatri ve genetik uzmanları ile birlikte psikolog ve sosyal çalışmacıların da içinde olduğu bir ekip tarafından izlemin yapılmasının en uygun yöntem olacağı aşikârdır.

HH'de geniş bir yelpazede kendini gösteren motor belirtiler en görünür ve en iyi bilinen bozukluklardır ve kore, bu yelpaze içinde en sık görülen motor bulgudur. Tedavisinde; eşlik eden depresyon ya da intihar fikri yok ise tetrabenazin, eşlik eden davranışsal problemler ve psikotik belirtiler varlığında ise ikinci kuşak antipsikotikler yüksek kanıt düzeyi ile birinci sırada önerilmektedir (Bachoud-Lévi ve ark 2019). Nöropsikiyatrik belirti ve bozuklukların tedavisinde ise yüksek kanıt düzeyine sahip araştırmalar yeterince yok ise de daha düşük kanıt düzeyine sahip araştırmalar, vaka bildirimleri ve uzman görüşüne dayalı çeşitli kılavuzlar literatürde yer almaktadır (Anderson ve ark. 2018, Loi ve ark. 2018, Bachoud-Lévi ve ark 2019, Stahl ve Feigin 2020). HH'de görülen nöropsikiyatrik bozuklukların tedavisine ilişkin öneriler bu kılavuz ve çalışmaların ışığında her bozukluk ya da belirti özelinde ayrı ayrı ele alınacaktır.

\section{Duygudurum Bozukluklar1}

$\mathrm{HH}$ olan bireylerde en sik görülen psikiyatrik bozukluklardan birinin depresif belirtiler olduğu bildirilmektedir (Morris 1991). Yapılan çalışmalarda HH'de görülen depresyonun prevelansı \%963 gibi geniş bir aralıkta bildirilse de, ağırlıklı olarak çalışmalar hastaların yaklaşık \%50'sinde hastalığın herhangi bir evresinde depresyon görüleceğine işaret etmektedir (Paoli ve ark. 2017). Martinez-Horta ve arkadaşlarının (2016) presemptomatik, semptomatik dönemin hemen öncesi ve erken-semptomatik dönemdeki $\mathrm{HH}$ olgularında yaptıkları çalışmalarında nöropsikiyatrik belirtilerin tahmini rölatif riskleri (oddsratio) sağlıklı kontrol grubuna kıyasla belirlenmeye çalışılmış, erken-semptomatik dönemdeki olguların \%65'inde depresyon saptandığı bildirilmiştir. Aynı çalışmada depresyon prevelansının HH'nin farklı evreleri arasında farkllık göstermediği bildirilmiş, 
bu sonuç, her ne kadar HH'deki depresyonun nörodejenerasyon (Slaughter ve ark. 2001) ve limbik yapılar ile bağlantıları olan medial kaudattaki erken hücre kaybı ile ilişkili olabileceği bildirilmiş olsa da (Gubert ve ark. 2020), sadece ilerleyici özellikteki nöropatoloji ile ilişkili olmayabileceği şeklinde yorumlanmıştır. Genetik bir hastalıktan etkilenmiş bir ebeveyn ile büyümenin yetişkin dönemdeki ruhsal sağlığı olumsuz etkilediği (van der Meer ve ark. 2014), yakın gelecekte gelişeceği bilinen belirtilerle ilgili belirsizlik ve hastalıktan etkilenen yakınlarının tedavisindeki güçlüklere tanıklık etme gibi etkenler de depresyon gelişiminde azımsanmayacak bir öneme sahiptir (Vamos ve ark. 2007).

HH'deki depresyonu sadece ileride gelişeceği bilinen ağır hastalık tablosuna yönelik tepki gibi yorumlamak da hatalı olacaktır. Gen taşıyıcılarının da, risk altında olan ancak mutant gen taşıyıcısı olmayanlara kıyasla daha sık depresyon görüldüğü bilinmekte, dolayısıyla HH'deki depresyonun yüksek prevelansını psikolojik ve psikososyal etkenlerle ilişkili biyolojik bir yatkınlıkla açıklamak daha doğru olacaktır (Goh ve ark. 2018). HH'deki depresyonun hastalığın en erken başlayan belirtilerinden biri olduğu bilinmekte ve hastalığın çekirdek belirtileri arasında kabul edilmektedir (Paoli ve ark. 2017, Paulsen ve ark. 2017). HH'deki depresyonun bilişsel becerileri olumsuz etkilediği bildirilmekte ancak hastalı̆̆ın ileri evrelerinde, bilişsel işlevselliğin ileri derecede bozulduğu hastalarda muhtemelen hastalığın farkındalığında azalma ile birlikte prevelansı da düşmektedir (Craufurd ve ark. 2001). Depresif belirtilerin en sik HH'nin ikinci evresinde görüldüğü, ilerleyen evrelerde giderek prevelansının düştüğü ve prevelansın CAG tekrar uzunluğu ile ilişkili olmadığı bildirilmektedir (van Duijn ve ark. 2014) Genel popülasyonda görülen depresyondan farklı olarak cinsiyetler arasında HH'deki depresyonun prevelansinda siklıkla belirgin bir farklılık olmadığı (Eddy ve ark. 2016), başlangıç yaşının ise HH'deki depresyonda genel popülasyondakinden yaklaşık 14 yll kadar önce olduğu bildirilmektedir (Paoli ve ark. 2017). Kilo kaybı, aktivitelerde azalma ve apati gibi HH'de de görülebilen bazı ortak belirti kümeleri nedeniyle depresyon tanısını koymak zorlaşabilmektedir (Eddy ve ark. 2016).

Depresyon HH mutant gen taşıyıcılarında yaşam kalitesini ve işlevselliği olumsuz etkilediğinden (Ready ve ark. 2008, Gibson ve ark. 2022) ve intihar riskini artırdığından (Kachian ve ark. 2019) mutlaka tedavi edilmelidir. HH'deki depresyonun tedavisiyle ilgili yüksek kanıt düzeyine sahip randomize kontrollü çalışmalar ya da metaanalizler bulunmamaktadır. Tedavi önerileri daha düşük kanıt düzeyine sahip vaka kontrol çalışmaları, vaka serileri/bildirimleri ve uzman görüşlerine dayanmaktadır. Bilişsel bozulmanın eşlik etmediği hafif depresyon varlı̆̆ında psikoterapi uygun bir seçenek olabilir (Stahl ve ark. 2020). Bilişsel davranış̧̧ı terapi (BDT) tekniklerini de içeren psikoeğitimin semptomatik ve presemptomatik olgularda (n:41) depresyon, kaygı ve baş etme becerilerine olumlu etkisi olduğu (A'Campo ve ark. 2012), semptomatik bir hastaya uygulanan BDT ile ilgili bir vaka bildiriminde ise orta düzeyde depresyon ve anksiyetesi olan hastanın belirtilerinin minimal düzeye indiği ve iyilik halinin 6 aylık izlemde devam ettiği saptanmıştır (Silver 2003). İlaç tedavisi olarak seçici serotonin geri alım inhibitörleri (SSGI), serotonin noradrenalin geri alım inhibitörleri (SNGİ), uyku bozukluğunun da eşlik ettiği durumlarda mianserin ya da mirtazapin kullanımı önerilmektedir. Tekrarlayıcı depresyon varlığında, antidepresana ek olarak duygudurum dengeleyici ajanlar kullanılabilir. Eğer depresyonun kullanılan başka bir ilacın yan etkisi olabileceği düşünülüyorsa, örneğin tetrabenazin, sorumlu olduğunu düşündüğümüz ilacın dozunu kademeli olarak azaltmak iyi bir seçenek olabilir. (Bachoud-Lévi ve ark. 2019). İlaç tedavisine dirençli, intihar riskinin yüksek olduğu ya da psikotik belirtilerin eşlik ettiği şiddetli depresyon varlığında elektrokonvulzif tedavi de bir seçenek olarak mutlaka akla gelmelidir (Adrissi ve ark. 2019, Bachoud-Lévi ve ark. 2019, Stahl ve ark. 2020).

Depresyon, HH'deki en sık psikiyatrik tanı olmasına rağmen, coşkulu ya da irritabl duygudurum, dürtüsellik, hareketlilik, uyku ihtiyacında azalma ve grandiyözite ile kendini gösteren mani tablosunun çok daha az sıklıkla görüldüğü bildirilmektedir (Paoli ve ark. 2017). HH'de, bipolar spektrumundaki sendromların prevelansının farklı tanı kriterlerinin kullanıldığı çalışmalarda \%5-10 aralığında bildirildiği göze çarpmaktadır. Presemptomatik hastalar da dahil olmak üzere disinhibisyon, irritabilite ve şakacılık gibi maniyi andıran kişilik değişikliklerinin HH'de yaygın olarak görülebileceğini ve manik dönem ile karışabileceğini de unutmamak gerekir (Goh ve ark. 2018). HH'de görülen manik dönemlerin tedavisi ile ilgili uzman görüşüne dayanan öneriler, standart tedavilere işaret etmektedir. Valproat ve karbamazepin gibi duygudurum düzenleyicilerin kullanılabileceği bildirilmektedir (Loi ve ark. 2018). Lityum ve valproatın HH'de hem nöroprotektif hem de duygudurum düzenleyici etkileri (sadece mani için değil aynı zamanda disinhibisyon ve irritabilite gibi belirti kümeleri için) nedeniyle kullanılabileceği bildirilmektedir (Scheuing ve ark. 2014). Danivas ve ark.'nın (2013) vaka serisinde, kore ve duygudurumda irritabilite ve agresyon gibi belirtileri olan olgulara karbamazepine ek olarak düşük doz (300mg/gün) lityum başlanmış, olguların ilerleyici kore belirtilerinde stabilizasyon sağlandığ 1 ve duygudurum belirtilerinin şiddetinde azalma olduğu bildirilmiştir. Tüm bu verilerden yola çıkarak, $\mathrm{HH}$ ve mani birlikteliğinde valproat, lityum ya da karbamazepin standart kullanım prensipleri dâhilinde uygulanabilecek seçenekler olarak değerlendirilebilir.

\section{Apati}

Apati; bilinçlilik düzeyinde azalma, bilişsel bozukluk ya da emosyonel strese bağlı olmayan motivasyonun azalması olarak tanımlanabilir. Bazı apati belirtilerini depresyon belirtilerinden ayırt etmek zor olsa da, apatinin depresyondan farklı ve ayrı bir durum olduğunun altını çizmek gerekir (Levy ve ark. 1998). Depresyon ve apatinin ortak özellikleri arasında ilgiistek azlığı, psikomotor retardasyon, enerji ve motivasyon azlığ sayılabilirken; üzüntü, disfori ve vejetatif belirtilerin (ör. uykusuzluk, yorgunluk, dikkat eksikliği) eşlik etmediği motivasyon azlığı daha çok apatiyi akla getirmelidir (Goh ve ark. 2018). Apati, HH'de en sık görülen nöropsikiyatrik tablolardan biridir (Camacho ve ark. 2018). Çalışmalar presemptomatik dönemdeki prevelansını \%11-64, semptomatik dönemdeki 
prevelansını ise \%47-76 aralığında bildirmektedir (Paulsen ve ark. 2001, Martinez-Horta ve ark. 2016). Apati, HH fenotipine dönüşümün ve hastalık progresyonunun önemli bir yordayıcısı olarak görülmekte, global ve yürütücü bilişsel performansla ilişkili olduğu bildirilmektedir (Goh ve ark. 2018). Martinez Horta ve ark.'nın çalışmasında (2016), semptomatik evrenin çok öncesindeki mutant gen taşıyıcılarında \%32, erken evre HH'de \%62 sıklığında apati saptanmıştır. Sağlıklı kontrollere kıyasla presemptomatik $\mathrm{HH}$ olgularında dahi apati görülme olasılığının 15-88 kat daha yüksek olduğu, bu riskin semptomatik evreye yaklaştıkça arttığı, semptomatik $\mathrm{HH}$ olgularında da riskin ve şiddetin presemptomatiklere kıyasla arttığı, apatinin hastalığın özelliği olan ilerleyici nörodejenerasyon ile yakından ilişkili oluğu bildirilmiştir (Martinez Horta ve ark. 2016). Apati belirtileri olan mutant gen taşıyıcılarının daha çok erkek cinsiyetten, genel işlevselliği düşük, apatik olmayanlara kıyasla daha çok benzodiazepin ve nöroleptik kullanan olgular oldukları ancak bahsedilen ilaçların apatiye neden olup olmadığının gösterilebilmesi için ileri çalışmalara ihtiyaç olduğu bildirilmektedir (van Duijn ve ark. 2010, Eddy ve ark. 2016).

Apati, amaca dönük hareketlerin, ilişkili bilişsel beceriler ve emosyonların azalması ile sonuçlanan bir sendrom olduğundan, günlük yaşam aktivitelerinde belirgin bir düşüşe neden olmakta, motor ve bilişsel beceri kayıplarından bağımsız olarak bakımveren yükünde ciddi artış ile sonuçlanmaktadır (Camacho ve ark. 2018). Bir kez saptandığında daha kötüye gitme eğiliminde olan apati belirtileri, en sık hastalığın son evresinde görülmekte ve bu evrede en şiddetli halini almaktadır (van Duijn ve ark. 2014, Paoli ve ark. 2017). Apatisi olan HH olgularında olmayanlara kıyasla bilişsel ve işlevsel düşüşün daha hızlı olduğu bilinmektedir (Paoli ve ark. 2017). Apatinin hastaların ve bakımverenlerinin yaşam kalitesine ve kurum bakımına giden süreçteki etkisinin büyüklüğü düşünüldüğünde, HH'nin çekirdek bir belirtisi olarak tedavisi daha da önemli hale gelmektedir (Camacho ve ark. 2018).

Apati, HH'nin çekirdek bir belirtisi olmasına ve işlevselliği ve bakımveren yükünü oldukça fazla etkileyen bir belirti kümesi olmasına rağmen üzerinde az çalışılmış bir alandır. Apatiyi de içeren motivasyonel bozuklukların anterior singulatsubkortikal bölgeler arasındaki devrelerin hasarından ve bazal gangliyonlar ve prefrontal kotreksin dorsolateral, orbitomedial ve dorsomedial bölümleri arasındaki işlevsel bağlantı bozukluğundan kaynaklanabileceği (Boyle ve ark. 2003, Goh ve ark. 2018), bildirilse de HH'deki apatinin etiyolojisi ve patofizyolojisi yeterince bilinmediğinden etkili bir şekilde henüz tedavi edilememektedir. Halen başarılı bir tedavi yöntemi olmasa da kişiselleştirilmiş bilişsel uyarım, rutinleri belirlemek ve günlük aktiviteleri bir program dahilinde yapılandırmak önerilen yaklaşımlardır (BachoudLévi ve ark 2019). A'Campo ve arkadaşlarının (2012), altı semptomatik evredeki $\mathrm{HH}$ olgusu ile olan vaka serilerinde apati için Tekrar Motivasyon Terapisi (Remotivation Therapy) uygulanmış; ilgi, farkındalık, dikkat, engellenme toleransı, okuma becerisi ve sözel iletişim alanlarında iyileşme sağlandığı bildirilmiştir. Bunların yanında eğer apatinin başka belirtiler için kullanılan ilaçlara bağlı olabileceği düşünülüyorsa (ör. antipsikotikler) ilgili ilacın dozunun azaltılması düşünülebilir. Apatiye yol açabilecek eşzamanlı bir depresyon olup olmadığı değerlendirilmeli, varsa tedavi edilmelidir. Depresyon ve apatinin ayırt edilemediği durumlarda antidepresan tedavi denenebilir (Anderson ve ark. 2018). Strassburger ve ark.'nın vaka serisinde (2008), 3 ay süren 300 mg/gün dozundaki bupropionun yedi hastanın birinde apati belirtilerinde düzelme sağladığı saptanmıştır. Her ne kadar metilfenidat, atomoksetin, modafinil, amantadin ve bromokriptin ile ilgili yapılan çalışmalar yeterince yüz güldürücü sonuçlar içermese de (Eddy ve ark. 2016), depresyonu olmayan apatik olgularda uyku bozukluğu ya da irritabilitede artış gibi yan etkilere dikkat ederek, aktive edici özelliği olan antidepresanlar ya da stimülan ilaçlar denenebilir (Anderson ve ark. 2018). Tüm bu önerilerin randomize kontrollü çalışmalara dayanan öneriler olmadığı, uzman görüşü düzeyinde kanıt seviyesine sahip olduğu da akılda tutulmalıdır.

\section{Anksiyete}

Her ne kadar HH'de anksiyete belirtileri sık görülüyor olsa da, $\mathrm{HH}$ ve anksiyete ilişkisi, HH'nin nöropsikiyatrik yönleri arasında az çalışılmış alanlardan birisidir. Semptomatik HH olgularındaki anksiyete prevelansı \%34-61 gibi geniş bir aralıkta -örneklemin hastalık evresinin ne olduğuna ve anksiyetenin ölçme/ değerlendirmesinde farklı araçlar kullanımına bağlı olarakbildirilmektedir (van Duijn ve ark. 2007). Semptomatik dönem öncesindeki mutant gen taşıyıcılarında ise prevelans farklı çalışmalarda \%0-17 aralığında bildirilmektedir (Dale ve van Duijn 2015). Semptomatik ve semptom öncesi evredeki HH olgularını anksiyete bozuklukları açısından karşılaştıran bir çalışmada panik bozukluk, agorafobi, yaygın anksiyete bozukluğu ve sosyal fobi tanılarının sıklığı açısından fark saptanmamıştır (van Duijn ve ark. 2008). Semptomatik dönem öncesindeki mutant gen taşıyıcıları ile mutant gen taşıyıcısı olmayanların kıyaslandığı çalışmalarda (Duff ve ark. 2007, Marshall ve ark. 2007), mutant gen taşıyıcılarında daha fazla anksiyete belirtisi saptanması HH'deki anksiyetenin altında hastalığa özgü bazı faktörlerin yatıyor olabileceğini düşündürmektedir.

HH'deki anksiyete belirtilerinin yaş, cinsiyet, CAG tekrar sayısı, motor işlevsellik, bilişsel beceriler, apati ve hastalık süresi/ progresyonu ile ilişkili olmadığı bildirilmektedir (Dale ve van Duijn 2015). Ancak anksiyetenin depresyon, ajitasyon ve irritabilite ile ilişkili olduğunu bildiren çalışmalar bulunmaktadır (Paulsen ve ark. 2001, Nimmagadda ve ark. 2011). Anksiyete ve intihar ilişkisi ile ilgili çalışma sonuçlarının karışık olduğu göze çarpmaktadır. Motor semptomatik dönemdeki 1941 HH olgusu ile yapılan çalışmada karışık depresyon/anksiyete faktörünün intiharı yordamadığı saptanırken (Wetzel ve ark. 2011), $2106 \mathrm{HH}$ mutant gen taşıyıcısı ile yapılan bir çalışmada ise anksiyetenin intihar fikrinin bağımsız yordayıcısı olduğu ancak 4 yıllık izlem sonucunda bu yordayıcılığın ortadan kalktığı bildirilmiştir (Hubers ve ark. 2013). Hastalığa ilişkin algı ve baş etme tarzının anksiyete ile ilişkili olduğunu bildiren bir çalışmada; hastalık kimliğini yoğun algılamanın ve tedaviye ilişkin düşük inancın 
anksiyete ile ilişkili olduğu, hastalığı kabul etmede güçlük ve kendini suçlama şeklindeki baş etme tarzlarının anksiyete seviyesini artırdığı saptanmıştır (Arran ve ark. 2014).

Tedavide öncelikle anksiyete ile ilişkili olabilecek psikiyatrik ve genel tıbbi durumla ilgili eş tanılar ile çevresel faktörler ele alınmalı ve gerekli müdahaleler yapılmalıdır (Anderson ve ark. 2018). Erken dönemdeki, bilişsel işlev kaybının belirgin olmadığı olgularda bilişsel davranışçı terapi ve bu terapi bileşenlerinin kullanıldığı psikoeğitimler anksiyete düzeyini azaltmada etkili olabilir (A'Campo ve ark. 2012). Depresyon ve anksiyete birlikteliğinde SSGİ ve SNGİ grubundan ilaçlar kullanılabilir. Anksiyetenin çok şiddetli olduğu durumlarda düşmeye yol açma ya da belirtilerin kötüleşmesi gibi riskler hakkında uyarıda bulunarak kısa süreliğine benzodiazepinler kullanılabilir (Bachoud-Lévi ve ark 2019). Siklıkla ilk tercih edilecek ilaç grubu olarak önerilen SSGI'lerin başlangıçta anksiyeteyi artırabileceği ve ilk bir ya da iki haftalık dönemde bu açıdan benzodiazepinlerden faydalanılabileceği unutulmamalı ancak ayaktan tedavi gören HH olgularında tüm seçenekler başarısız olmadığı sürece uzun süre benzodiazepin kullanılmamalıdır (Anderson ve ark. 2018). Kullanılan bir SSGİ ajana yanıt alınamaz ise başka bir SSGI denenebileceği gibi, SNGİ olan bir ajan ya da obsesif belirtiler eşlik ediyorsa klomipramin de kullanılabilir. Uykusuzluğun eşlik ettiği durumlarda mirtazapin, diğer tedavi seçeneklerinin başarısız olduğu ve kore belirtilerinin eşlik ettiği hastalarda olanzapin (Squitieri ve ark. 2001) seçenekler arasındadır (Anderson ve ark. 2018).

HH ve anksiyete birlikteliği çalışmaya oldukça açık bir alan olarak göze çarpmaktadır. Anksiyetenin ne kadarının (epi)genetik, ne kadarının hastalığın biyolojik yapısı, ne kadarının ailesel ve psikolojik faktörlere bağlı olduğu henüz bilinmemektedir. Tedavi alanında da hem farmakolojik hem de psikoterapotik yaklaşımlar açısından daha yüksek güce sahip çalışmalara ihtiyaç duyulduğu aşikârdır.

\section{İntihar}

HH'de artmış intihar riskine, hastalığa ismini veren ve hastalığın özelliklerinden birini "deliliğe ve intihara yatkınlı" şeklinde tanımlayan George Huntington tarafından da dikkat çekildiği görülmektedir (Huntington 1872). Bir çalş̧mada, Amerika Birleşik Devletleri (ABD) ve dünya popülasyonunda, HH olgularında intihar düşüncesi, intihar girişimi ve intihar oranlarına yer verilmiş (Kachian ve ark. 2019), HH'de intihar düşüncesi oranı \%20-30, intihar girişimi oranı \%7-10, intihar oranı \%4,8-6,6 olarak bildirilirken; dünya popülasyonunda bu oranlar sirasıyla \%8-24,9; \%1,3-3,5; \%1,5 ve ABD popülasyonunda ise sırasıyla \%5,6-14,3; \%1,9-8,7 ve \%1,4 olarak bildirilmiştir (Nock ve ark. 2008). Frontotemporal demans (FTD) ve HH'de intiharı inceleyen güncel bir araştırmaya 106 aileden $\mathrm{HH}$ ya da FTD tanılı 267 birey dahil edilmiş, HH tanılı 160 bireyden 7'sinde tamamlanmış intihar saptanmıştır (59 ailenin 6'sında). HH alt grubunda intihar oranı 4375/100,000 iken, FTD'de bu oran 934/100,000, Avustralya popülasyonunda ise 10/100,00 olarak bildirilmiştir (Sexton ve ark. 2020). Genel popülasyona göre intihar ile ölüm riski HH olan grupta 400 kat kadar artmış olarak hesaplanırken, ortalama intihar yaşı da 52,5 (35-73 yaş) olarak bildirilmiştir. Aynı çalışmada 15 aileden (FTD ve HH ailelerinde) 1'inde intihar görülürken, 5 aileden 1'inde - genetik olarak etkilenmiş, etkilenmemiş ya da presemptomatik aile üyelerinden biri ya da fazlasında- intihar düşüncesi, girişimi ya da intihar görüldüğü bildirilmiştir. Bu oran $\mathrm{HH}$ olan ailelerde daha sik olup, \%30'lara varan oranlarda görülmektedir (Sexton ve ark. 2020). Çalışmalarda farklı evrelerdeki hastalar farklı değerlendirme araçları ile değerlendirildiğinden farklı oranlara ulaşılmış olsa da, genel olarak HH'de intihar düşüncesi prevelansının ortalama \%20 olduğu düşünülmektedir (Honrath ve ark. 2018). İntihar girişim oranı ise sıklıkla \%7 olarak bildirilmektedir (van Duijn ve ark. 2014, 2018). Rodrigues ve ark.'nın (2017) geniş örneklemli çalı̧masında ise (n: 5164) tamamlanmış intihar oranı \%6,6 olarak saptanmıştır. Çalışmalar farklı oranlara işaret etse de HH'de intihar, intihar düşüncesi ve girişiminin genel popülasyondan, hatta diğer kronik nörodejeneratif hastalıklardan daha sık görüldüğü (Ishihara ve ark. 2021), bu hastaların takibinde mutlaka akılda tutulması ve sorgulanması gereken bir durum olduğu açıktır.

İntiharın hangi $\mathrm{HH}$ olgularında daha sık görüldüğü önemli bir sorudur. Cinsiyet bir risk faktörü olabilir mi, sorusuyla ilgili çalı̧̧malar çelişkili sonuçlar bildirmektedir. Erkek cinsiyetin intihar için (Solberg ve ark. 2018), kadın cinsiyetin ise intihar düşüncesi ve davranışı açısından risk faktörü olduğunu bildiren çalı̧̧maların (Fiedorowicz ve ark. 2011, Wesson ve ark. 2018) yanında cinsiyetin intihar ve ilişkili durumlar için bir risk faktörü olmadığını bildiren çalışmalara da (van Duijn ve ark. 2018) rastlanmaktadır. Depresyon ve irritabilite, intihar davranışı ve düşünceleri ile ilişkili bulunan klinik özelliklerdendir (van Duijn ve ark. 2018). Anksiyete, umutsuzluk ve agresyon (Anderson ve ark. 2016), geçmiş intihar girişimi öyküsü (Fiedorowicz ve ark. 2011, Anderson ve ark. 2016), antidepresan ve benzodiazepin kullanıyor olmak (Hubers ve ark. 2013) diğer risk faktörleri arasında değerlendirilebilir. Alkol/madde kötüye kullanımı ise intihar düşüncesinin şiddeti ile ilişkili bulunmuştur (Wetzel ve ark. 2011). Mutant gendeki CAG tekrar sayısı ile intihar davranışı arasında ilişki bulunmazken (Hubers ve ark. 2013), hastalığın evresi ile intihar davranışının farklı yönlerinin ilişkili olabileceğine dair veriler bulunmaktadır. Paulsen ve arkadaşlarının (2005) HH'nin evrelerine göre intihar riskini değerlendirdikleri çalı̧̧malarında, Huntington Çalışma Grubunun veri tabanı kullanılmış (n:4171), erken evre (Evre 1) ve son evre (Evre 5) arasında katılımcılar sınıflandırlmış, intihar düşüncesinin en sık hastaların bağımsız yaşam becerilerini kaybetmeye başladığı Evre 2 hastalarda görüldüğü $(\% 21,6)$, sonraki evrelerde intihar düşüncesi sıklığının azaldığı saptanmıştır. İntihar davranışının ise daha ileriki dönemlerde (Evre 4/5) daha yüksek olduğu bildirilmektedir (van Duijn ve ark. 2018). Yine prodromal dönem olarak nitelendirilen motor semptomatik dönem öncesi dönem incelendiğinde motor tanı kriterlerin karşılanmadığı ancak muhtemel $\mathrm{HH}$ denilebilecek hafif motor belirtilerin olduğu dönemde de intihar düşüncesinin sık görüldüğü bildirilmektedir (Paulsen ve ark. 2005). Görüldüğü üzere bazı klinik özellikler 
ve bazı kritik dönem ve evreler HH'deki intihar düşüncesi ve davranışı ile ilişkili görülmekte, bu özelliklere sahip hastalarda intiharı sorgulamak özellikle önem taşımaktadır.

HH'de intihar düşünce ve davranışlarının medikal tedavisi ile ilgili yeterli veri yoktur ancak intiharı önlemede altta yatan depresyon, sosyal izolasyon ve dürtüsellik gibi risk faktörlerine müdahale etmek etkin yöntemler arasında sayılabilir (BachoudLévi ve ark 2019). HH'nin motor belirtilerinin tedavisinde kullanılan tetrabenazinin depresyon ve intihar riskinde artışa neden olabileceği de akılda tutulmalıdır (Bayram ve ark. 2015). İntiharın tedavisi ile ilgili literatürde daha çok vaka bildirimleri yer almaktadır; Greenberg ve arkadaşları (2020), şiddetli intihar düşüncesiolan, fluoksetineyanıtvermeyen, tetrabenazin ilekliniği kötüleşen bir olgunun paroksetin ve lityum kombinasyonuna yanıt verdiğini bildirmişlerdir. Tetrabenazin kullanan bir hastada depresyon ya da intihar düşüncesi saptandığında kore tedavisi için daha güvenilir alanda bulunan deutetrabenazin, amantadin ya da riluzol tercih edilebilir ya da uygun vakalarda tetrabenazine antidepresan eklenerek de klinik belirtilerde düzelme sağlanabilir (Bayram ve ark. 2015, Greenberg ve ark 2020). Depresyon HH'deki intiharın en güçlü yordayıcısı olduğundan (van Duijn ve ark. 2018), intiharı önlemede en önemli müdahalenin depresyonu tanımak ve tedavi etmek olduğunu söylemek yanlış olmayacaktır.

\section{İrritabilite, Agresyon, Dürtüsellik}

İrritabilite, öznel olarak hoş olmayan, nesnel olarak da kişilerarası ilişkilerde olumsuz emosyonlara neden olan, belirli duygular (ör. öfke), belirli bilişler (ör. Düşmanca değerlendirmeler) ve belirli eylemlere (ör. saldırganlık) yatkın ruh hali, kısaca öfkeye yatkınlık hali olarak tanımlanabilir (Craig ve ark. 2008). Kliniğe, ani ve öngörülemeyen öfke patlamaları şeklinde yansıdığı gözlenir. Etiyolojisinde HH'ye ilişkin nörobiyolojik mekanizmaların (striatum ve orbitofrontal-subkortikal devrelerde dejenerasyon) yanı sıra ilerleyici bilişsel kayıpların neden olduğu bilişsel aşırı yüklenme gibi psikolojik nedenlerin de olduğu düşünülmektedir (Karagas ve ark. 2020). İrritabilite daha çok aileler tarafından bildirilmekte, bilişsel becerilerin henüz belirgin olarak etkilenmediği dönemlerde dahi hastalar irritabilitenin farkında olmayabilmektedir (Chatterjee ve ark. 2005). Dahası yoğun öfke patlamaları ve saldırgan davranış ile sonuçlanabilen irritabilite kişilerarası ilişkileri olumsuz etkileme, hastanın sosyal desteğinin zayıflaması, boşanma ve hatta tutuklanma gibi olumsuz sonuçlara neden olabilmektedir (Karagas ve ark. 2020). Chu ve ark.'nın yazısında (2019), motor belirtiler başlamadan önceki dönemde farklı suçlar nedeniyle tutuklanan ve $\mathrm{HH}$ için mutant gen taşıyıcısı olan üç kadın hasta bildirilmiş, henüz tipik nörolojik, bilişsel ya da psikiyatrik belirtiler başlamadan önce hastalıkla ilişkili irritabilitenin muhtemel sonuçlarına dikkat çekilmiştir.

Motor semptomatik dönem öncesindeki hastalarda sıklıkla hastalığın ilk belirtisi olarak tarif edilen irritabilitenin (van Duijn ve ark 2008), HH'de \%35-73 aralığında görüldüğü (Paoli ve ark. 2017), her hastada ilk belirti olarak irritabilitenin olmayabileceği, hastalığın herhangi bir evresinde de ortaya çlkabileceği ancak motor nörolojik belirtileri olan hastalarda daha sık görüldüğü ve bu sıklığın ve irritabilitenin şiddetinin hastalık evresi ilerledikçe arttığı bildirilmektedir (Thompson ve ark. 2012). İrritabilite, dürtüsellik ve agresyon birbiriyle ilişkili klinik görünümler olarak değerlendirilmekte, HH'deki agresyon prevelansı ise \%22-66 aralığında bildirilmektedir (Goh ve ark. 2018). Çalışmaların oldukça geniş aralık içinde değişen sıklıklara işaret etmesi kullanılan ölçüm araçları, çalışmalarda kullanılan kesme değerlerinin farklı olması ve örneklemlerdeki farklılık ile ilişkili görünmektedir. Genetik risk altındaki bireylerle yapılan ve yaklaşık 4 yıl süren bir izlem çalışmasında, $\mathrm{HH}$ mutant geni taşıma açısından riskli bireyler çalışmaya alınmış, bireylere genetik test yapılmış, çalışmacıların genetik test sonuçlarına kör olduğu çalışmada izlem sürecinde mutant gen taşıyıcısı olanlarda anlamlı olarak irritabilite ve hostilitenin zaman içerisinde daha fazla arttığı, bu artışın CAG tekrar sayısı ile ilişkili olmadığı saptanmıştır (Kirkwood ve ark. 2002). Reedeker ve arkadaşlarının çalışmasında (2012b) ise, CAG tekrar sayısı irritabilite ile ilişkili bulunmuştur. Aynı çalışmada evli olma/ birlikte yaşama ve benzodiyazepin kullanımı da irritabilite ile ilişkili özellikler olarak saptanmıştır (Reedeker ve ark. 2012b). Van Duijn ve arkadaşları (2014) ise, irritabilite/agresyonun erkek cinsiyet, genç yaş, depresyon, psikoz ve intihar girişimi öyküsü ile ilişkili olduğunu bildirmektedir. İrritabilite ve agresyonun HH'deki sıklığı ve sonuçları değerlendirildiğinde hem hastalar hem de aileleri için yaşam kalitesini olumsuz etkilediği, önemli bir stres etmeni olduğu ve profesyonel bakım hizmeti ihtiyacını artıran yönü yadsınamaz (Reedeker ve ark. 2012b). Bu nedenle tanınmasının ve tedavi edilmesinin oldukça önemli olduğunu söyleyebiliriz.

HH'deki irritabilitenin tedavisi için özel olarak onaylanmış bir tedavi seçeneği henüz olmasa da bu alanda çalışan klinisyenlerin önerdiği ve ağırlıklı uzman görüşüne dayalı bazı tedavi algoritmaları bulunmaktadır (Groves ve ark. 2011). Farmakolojik tedavi öncesinde hastada irritabilite ya da engellenmişlik duygusuna yol açabilecek çevresel faktörler ele alınmalıdır (ağrı, aşırı gürültü gibi fazla uyarılmaya neden olabilecek etkenler, karşılanmamış ihtiyaçlar, kullanılan ilaçlara bağlı akatizi vb. yan etkiler gibi). İrritabiliteyi azaltmak için öncelikle davranışsal yöntemlere başvurulması önerilir. Sakin bir ortam sağlanmalı; hastanın, düzenli olmasına özen gösterilen günlük rutin bir programı olmalıdır. Hastanın dikkatini başka uyarana vermesine ilişkin stratejiler psikoeğitim yoluyla bakımverenlere öğretilmeli, mümkün olduğunca yüzleştirmeden uzak durmaları sağlanmalıdır (Bachoud-Lévi ve ark. 2019). İrritabilite tedavisinde birinci sirada sıklıkla SSGİ grubundan ilaçların önerildiği görülmektedir (Groves ve ark. 2011, Bachoud-Lévi ve ark 2019). Kullanılan SSGİnin hangisi olması gerektiği ile ilgili bir öneri bulunmazken doz olarak ilgili ilacın önerilen en yüksek dozuna kadar çıkılması gerektiği bildirilmektedir. SSGİden yeterli yanıt alınamadığında özellikle uykusuzluğun eşlik ettiği hastalarda tedaviye mirtazapin ya da mianserin eklenebilir. (Bachoud-Lévi ve ark 2019). İkinci kuşak antipsikotikler sıklıkla ikinci sırada tercih edilen ajanlar olup, SSGİ'ye yanıt vermeyen, psikozun eşlik ettiği, belirgin agresyonun olduğu, dürtüselliğin ön planda olduğu, hiperseksüelitenin eşlik ettiği olgularda ilk tercih ikinci kuşak antipsikotiklerdir (Groves 
ve ark. 2011). Antidopaminerjik ajanların kore ve irritabilite tedavisinde etkin olmalarının yanı sıra bilişsel performanstaki azalmayı artırdıklarına da dikkat çekilmektedir (Harris ve ark. 2020). Duygudurum dengeleyici olarak kullanılan antiepileptik ajanlar sıklıkla üçüncü sırada tercih edilmekte, antidepresana ya da antipsikotiklere yeterli yanıt alınamadığında tek başına ya da kombine tedavi olarak kullanılması önerilmektedir (BachoudLévi ve ark 2019). Benzodiyazepinler tek başına (tolerans gelişmesi, bağımlılık ve düşme gibi riskler nedeniyle) sıklıkla tercih edilmemekte, genellikle diğer tedavilere kısmi yanıt alındığında kısa süreli ekleme tedavi olarak kullanılmaktadır (Groves ve ark. 2011), Her ne kadar irritabiliteden farklı bir durum olsa da ajitasyon da HH'de görülebilmekte, akut ajitasyon durumunda benzodiyazepinler ve antipsikotikler birinci sirada önerilirken, kronik ajitasyon ve kendine/başkasına zarar verme riski durumunda antipsikotikler ve duygudurum düzenleyici antiepileptikler daha ön plana çıkmaktadır (Rossi ve Oh 2020).

\section{Obsesiflik/Perseverasyon}

Obsesif ve kompulsif belirtilerin HH'deki prevelansı, katı tanı kriterlerinden bağımsız olarak değerlendirildiğinde, \%20-50 aralığında bildirilmekte, genelpopülasyonakıyasla sıklığın oldukça fazla olduğu anlaşılmaktadır (Goh ve ark. 2018). Perseveratif davranış; bir yanıtın (motor davranış, sözcük, düşünce, aktivite, strateji, ya da emosyon gibi), kaynaklandığı neden ya da bağlamdan bağımsız bir şekilde kontrol dışı tekrarlanması ya da devam ettirilmesi olarak tanımlanır. Obsesif ve kompulsif belirtilerden farklı olarak kişinin bu davranışa ilişkin farkındalığı ya da içgörüsü genellikte yoktur ve sıklıkla kişiyi rahatsız etmez (Serpell ve ark. 2009). Perseverasyonun ve obsesif kompulsif belirtilerin kortikostriatal devrelerin etkilendiği HH'de benzer nörobiyolojik alt yapısı olduğu, aynı yelpazede değerlendirilebilecekleri, motor belirtiler başlamadan çok önce başlayan ve kişilik değişimi yelpazesinde değerlendirilen bilişsel esneklik kaybının bu iki klinik görüngünün öncülü olduğu bildirilmektedir (Paoli ve ark. 2017). HH'de perseveratif davranışlar daha sık görülmekte, \%75’e varan oranlar bildirilmektedir (Oosterloo ve ark. 2019). Sadece motor semptomatik hastalarda değil aynı zamanda motor belirtiler başlamadan önceki dönemdeki mutant gen taşıyıcılarında da genel popülasyona göre obsesif ve kompulsif belirtiler daha sıktır (van Duijn ve ark. 2008). Beglinger ve arkadaşlarının çalışmasında (2008), presemptomatik dönemdeki mutant gen taşıyıcılarının CAG tekrar sayılarına göre tahmini hastalık başlangıç yaşlarına yakınlıkları hesaplanmış ve hastalık başlangıcına (burada kastedilen motor belirtilerin başlamasıdır) yakınlık arttıkça obsesif ve kompülsif belirtilerin sıklığının arttığı saptanmıştır.

En sık agresif ve bulaş temalı obsesyonlar ile kontrol içerikli ritüellerin görüldüğü saptanmıştır (Goh ve ark. 2018). van Duijn ve ark. (2014), perseveratif/obsesyonel düşünce ve kompulsif davranış prevelansının hastalığın progresyonu ile birlikte arttı̆̆ını, hastalığın birinci evresinde prevelans \%4,5 iken, üçüncü evrede \%25’lere kadar çıktığını saptamıştır. Aynı çalışmada, obsesif/ kompulsif belirtileri ve perseveratif davranışları olan hastaların olmayanlara kıyasla daha uzun hastalık süresine sahip olduğu, depresyon ya da psikoz gibi bir psikiyatrik hastalık öyküsüne bu olgularda daha sık rastlandığı ve daha fazla psikiyatrik ilaç kullandıkları bulunmuştur (van Duijn ve ark. 2014). Sonuç olarak obsesif/kompulsif belirtiler ve perseveratif davranışlar hastalığın ilerlemesiyle daha sık ve şiddetli hale gelmekte, bu hastaların yürütücü işlevleri daha bozuk ve işlevsellikleri daha düşük olmaktadır (Oosterloo ve ark. 2019).

HH'de obsesif/kompulsif belirtilerin görülme sıklığı ve bu komorbiditenin getirdiği yükler düşünüldüğünde tedavisi hem hasta hem de bakımverenler için oldukça önemli hale gelmektedir. Ancak diğer tüm nöropsikiyatrik bozukluklarda olduğu gibi HH'deki bu belirtilerin tedavisi için de kanıta dayalı kılavuzlar bulunmamakta daha düşük kanıt düzeyine sahip vaka bildirimi/serisi ve uzman görüşüne dayalı algoritmalar bulunmaktadir. Hem obsesif ve kompulsif belirtilerin, hem de perseveratif davranışların tedavisinde, özellikle de anksiyetenin ön planda olduğu hastalarda, birinci sırada SSGI'ler önerilmekte (bir trisiklik antidepresan olan klomipramin de çoğu zaman bu gruba dâhil edilmektedir), irritabilitenin eşlik ettiği düşence temelindeki perseverasyonlarda ise olanzapin ve risperidonun önerildiği görülmektedir (Eddy ve ark. 2016, Bachoud-Lévi ve ark 2019). Bilişsel becerileri göreceli olarak korunmuş olgularda bilişsel davranışçı terapi de seçenekler arasındadır (Bachoud-Lévi ve ark. 2019).

\section{Psikoz}

HH'de psikotik belirtiler diğer nöropsikiyatrik durumlara kıyasla daha nadir görülmekte, HH'deki psikoz prevelansının \%311 olduğu bildirilmektedir (van Duijn ve ark. 2008). HH olan hastalarda hezeyanların ve halüsinasyonların nokta prevelansı sırasıyla \%10-11,5 ve \%1,9-3 olarak bildirilmiştir (Paulsen ve ark. 2001, Thompson ve ark. 2012). Jaini ve arkadaşlarının (2020) 7966 motor semptomatik dönemdeki HH tanılı hastayı değerlendirdikleri çalışmalarında, hastaların \%12,95'inde psikotik belirti öyküsü olduğu, psikoz başlangıç yaşının ortalama 48 olduğu ve HH motor belirtilerinin başlangıç yaşıyla örtüştügü, psikoz öyküsü olan hastaların birinci derece yakınlarının \%23,6'sında psikoz öyküsü olduğu saptanmıştır. Aynı çalışmada düşük eğitim seviyesi, işsizlik, bekar olma, depresyon, sözel akıcılıkta azalma ve toplam işlevsellik kapasitesinde azalmanın psikoz ile ilişkili olduğu bulunmuştur. van Duijn ve arkadaşlarının (2014), geniş örneklemli Avrupa kohortu çalışmasında psikozun en sık hastalığın üçüncü evresinde görüldüğü saptanmıştır. Hastalık evresi ilerledikçe ve bilişsel beceri kaybının da artmasıyla psikotik belirtilerde azalma görülebileceği söylenmektedir (Goh ve ark. 2018). Bununla birlikte motor belirtilerden önce de psikotik belirtilerin başlayabileceği bildirilmektedir (Kar ve ark. 2017). Presemptomatik ve semptomatik dönemdeki $\mathrm{HH}$ olgularının mutant gen taşıyıcısı olmayan ancak $\mathrm{HH}$ tanılı ebeveyne sahip olan kontrollerle kıyaslandığı çalışmada, motor belirtiler açısından hem klinik hem de preklinik dönemde olan mutant gen taşıyıcılarının paranoid düşünce ve psikotizm skorlarının kontrollerden anlamlı derecede daha yüksek olduğu saptanmıştır (Marshall ve ark. 2007). Motor belirtilerden önce başlayan psikoz çoğu zaman motor belirtilerin başlamak 


\begin{tabular}{|c|c|c|c|}
\hline $\begin{array}{l}\text { Semptom } \\
\text { Alan1 }\end{array}$ & Tedavi & Öneriler & Uyarılar \\
\hline Apati & $\begin{array}{l}\text { Semptomun } \\
\text { tedavisini direkt } \\
\text { hedefleyen } \\
\text { ilaç önerisi } \\
\text { bulunmamaktadır. }\end{array}$ & $\begin{array}{l}\text { Kişiselleştirilmiş bilişsel uyarım, } \\
\text { Rutinleri belirlemek, } \\
\text { Günlük aktiviteleri bir program dâhilinde yapılandırmak, } \\
\text { Aktive edici AD’ler/stimülanlar önerilir. }\end{array}$ & $\begin{array}{l}\text { Antipsikotiklere bağlı olduğu } \\
\text { düşünülüyorsa AP dozunu } \\
\text { azaltmak, } \\
\text { Depresyona bağlı apatide ya } \\
\text { da depresyon-apati ayrımı } \\
\text { yapılamadığında AD eklemek } \\
\text { önerilmektedir. }\end{array}$ \\
\hline Anksiyete & $\begin{array}{l}\text { BDT } \\
\text { SSGİ (ilk tercih) } \\
\text { SNGİ } \\
\text { BZD } \\
\text { TSA } \\
\text { NASSA } \\
\text { AP }\end{array}$ & $\begin{array}{l}\text { Bilişsel bozulmanın eşlik etmediği anksiyetede BDT, } \\
\text { Şiddetli anksiyete varlığında düşme riskine karşı uyarıda } \\
\text { bulunularak kısa süreli BZD, } \\
\text { Obsesif belirtiler de eşlik ediyorsa klomipramin, } \\
\text { Uykusuzluk eşlik ediyorsa mirtazapin, } \\
\text { Kore belirtilerinin eşlik ettiği vakalarda diğer seçenekler } \\
\text { başarısız olursa olanzapin önerilmektedir. }\end{array}$ & $\begin{array}{l}\text { Bir SSGİ başarısız olursa } \\
\text { ikinci seçenek olarak tekrar } \\
\text { bir SSGİ denenebileceği gibi, } \\
\text { ikinci seçenekte bir SNGİ de } \\
\text { kullanılabilir. } \\
\text { Yan etkiler ve düşme riski } \\
\text { nedeniyle BZD’lerin uzun süreli } \\
\text { kullanımından kaçınılmalıdır. }\end{array}$ \\
\hline İntihar & $\begin{array}{l}\text { Semptomun } \\
\text { tedavisini direkt } \\
\text { hedefleyen } \\
\text { ilaç önerisi } \\
\text { bulunmamaktadır. }\end{array}$ & $\begin{array}{l}\text { Depresyon, sosyal izolasyon ve dürtüsellik gibi risk } \\
\text { faktörlerine müdahale etmek önerilmektedir. Depresyon } \\
\text { bu risk faktörlerinin en önemlisi olduğu için tanınması ve } \\
\text { tedavi edilmesi çok önemlidir. }\end{array}$ & $\begin{array}{l}\text { Tetrabenazin intihar riskini } \\
\text { artırabileceği unutulmamalıdır. }\end{array}$ \\
\hline $\begin{array}{l}\text { Obsesiflik } \\
\text { Perseverasyon }\end{array}$ & $\begin{array}{l}\text { SSGİ } \\
\text { TSA } \\
\text { AP } \\
\text { BDT }\end{array}$ & $\begin{array}{l}\text { Bilişsel becerileri göreceli olarak korunmuş olgularda BDT, } \\
\text { İlk tercih olarak SSGİ ya da klomipramin, } \\
\text { İrritabilite ve düşünsel perseverasyon varlığında olanzapin } \\
\text { ya da risperidon önerilmektedir. }\end{array}$ & \\
\hline Psikoz & $\begin{array}{l}\mathrm{AP} \\
\mathrm{EKT}\end{array}$ & $\begin{array}{l}\text { İkinci kuşak AP’ler ilk sırada tercih edilmektedir. } \\
\text { Klozapin dirençli olgularda ya da akinetik HH olgularında ilk } \\
\text { tercih olarak önerilir. } \\
\text { Tedaviye yanıt vermeyen hastalarda EKT bir seçenek olarak akla } \\
\text { gelmelidir. }\end{array}$ & $\begin{array}{l}\text { Belirtilerin akut olarak başlamasına } \\
\text { neden olabilecek tıbbi durumlar ile } \\
\text { ayırıcı tanısı yapılmalıdır. } \\
\text { Perseveratif düşüncelerin psikozu } \\
\text { taklit edebileceği unutulmamalıdır. }\end{array}$ \\
\hline $\begin{array}{l}\text { Uyku } \\
\text { Bozuklukları }\end{array}$ & $\begin{array}{l}\text { Modafinil } \\
\text { Melatonin } \\
\text { Melatonin reseptör } \\
\text { agonistleri } \\
\text { NASSA } \\
\text { TSA } \\
\text { İkinci kuşak AP } \\
\text { BZD }\end{array}$ & $\begin{array}{l}\text { Uyku hijyeni ile ilgili müdahaleler, } \\
\text { Aşırı uykululuk durumunda modafinil, } \\
\text { Uykusuzluk halinde melatonin, agomelatin ya da ramelteon, } \\
\text { Ya da mirtazapin/trazadon gibi hipnotik etkili AD’ler, } \\
\text { Obsesif belirtiler de eşlik ediyorsa klomipramin, } \\
\text { AP tercih edilecekse olanzapin ya da ketiyapin, } \\
\text { Tüm seçenekler başarısız kaldığında BZD’ler önerilmektedir. }\end{array}$ & $\begin{array}{l}\text { Motor belirtilere ya da huzursuz } \\
\text { bacaklar sendromuna sekonder } \\
\text { olup olmadığı değerlendirilmelidir. } \\
\text { BZD’ler düşme riskinden dolayı } \\
\text { son tercih olmalıdır. }\end{array}$ \\
\hline
\end{tabular}




\begin{tabular}{|l|l|l|l|}
\hline \multicolumn{2}{|l|}{ Tablo 1 (devamı). Huntington Hastalı̆̆nda sık görülen nöropsikiyatrik bozuklukların tedavisi } \\
\hline $\begin{array}{l}\text { Semptom } \\
\text { Alanı }\end{array}$ & Tedavi & Öneriler & Uyarılar \\
\hline $\begin{array}{l}\text { Cinsel İşlev } \\
\text { Bozuklukları }\end{array}$ & $\begin{array}{l}\text { AP } \\
\text { Cinsel terapiler/ } \\
\text { Psikoeğitim }\end{array}$ & $\begin{array}{l}\text { Hiperseksüel davranış varlığında haloperidol/olanzapin } \\
\text { Hiposeksüel davranı̧ varlığında genel tedavi prensiplerinin } \\
\text { uygulanması ve psikoeğitim önerilir. }\end{array}$ & \\
\hline
\end{tabular}

BDT: Bilişsel Davranış̧ı Terapi, SSGİ: Seçici Serotonin Geri Alım İnhibitörleri, SNGİ: Serotonin Noradrenalin Geri Alım İnhibitörleri, NASSA: Noradrenerjik ve Spesifik Serotonineriik Antidepresanlar, DDD: Duygudurum Dengeleyici, EKT: Elektrokonvulzif Tedavi, AP: Antipsikotik, AD: Antidepresan, BZD: Benzodiazepin, TSA: Trisiklik Antidepresan

üzere olduğunun habercisi olarak yorumlanmaktadır (van Duijn ve ark. 2007). Yirminci yüzyılın birinci yarısına kadar HH olan hastaların sıklıkla dementia praekoks ya da şizofreni olarak yanlıs tanı aldığı, HH'deki psikozun organik olmayan psikozların kliniği ile ayırt edici bir özelliğinin bulunmadığı, en sık perseküsyon hezeyanlarının görüldüğü, halen HH'deki psikoz prevelansının görece düşük olmasının nedeninin eşlik eden hareket bozukluklarının tedavisinde sıklıkla antipsikotiklerin kullanılıyor olmasının olabileceği söylenmektedir (Paoli ve ark. 2017, Goh ve ark. 2018).

Connors ve arkadaşlarının (2020) 5 yıllık izlem çalı̧smasında (n:1082), psikozun eşlik ettiği ve etmediği $\mathrm{HH}$ olan hastalar karşılaştırılmış, bu 5 yllık izlemde hastaların \%17,6'sında psikotik belirtilerin görüldüğü, psikozu olan olguların bilişsel becerilerinin ve işlevselliklerinin daha kötü, davranışsal problemlerinin ise daha fazla olduğu bildirilmiştir. HH'deki psikozun ailelerde kümelenme gösterdiği ve CAG tekrar sayısı arttıkça hem motor belirtilerin hem de psikozun daha erken yaşta başlama eğiliminde olduğu bildirilmektedir (Tsuang ve ark. 2000). Aynı zamanda, psikozu olan HH olgularında psikozu olmayanlara göre korenin daha az görüldüğü, antipsikotik ve tetrabenazin kullanımı açısından gruplar eşitlendiğinde de bu farkın devam ettiği saptanmıştır (Connors ve ark. 2020). Bu bulgular HH'de ayrı bir genetik alt yapısı olan psikotik bir endofenotipi düşündürse de henüz bu özellikteki hastaları ayırt eden genetik bir özellik tanımlanmamıştır.

Psikozun eşlik ettiği HH olgularının da sıklıkla hastaneye özellikle de psikiyatri kliniklerine yatırılarak tedavi edilmesi gerektiği, eşlik eden psikozun bu hastaların ev ortamında bakımına engel olduğu görülmektedir (Salman ve ark. 2018, Ataöv ve ark. 2020). Psikotik belirtiler saptandığında öncelikle bu belirtilerin akut olarak başlamasına neden olabilecek tıbbi durumlar (enfeksiyöz, metabolik, toksik, ilaç ilişkili nedenler, madde kullanımı, deliryum) ile ayırıcı tanısı yapilmalıdır (Anderson ve ark. 2018). Perseveratif düşünceler bazen psikotik belirtileri taklit edebildiğinden ayırıcı tanıda akla gelmeli ve perseverasyon varlığında daha önce de belirtildiği üzere serotoninerjik antidepresanlar ile müdahale yapılmalıdır. Varsanı ve hezeyan gibi psikotik belirtilerin varlığında ikinci kuşak antipsikotikler birinci sırada önerilen ajanlardır ve kanıt gücü uzman görüşü düzeyindedir (Bachoud-Lévi ve ark 2019). Kullanılan ajana ilişkin maksimum dozun üzerine çıkmak ya da antipsikotik ajanları kombinasyon şeklinde kullanmak önerilmemektedir (Anderson ve ark. 2018). Klozapin sıklıkla diğer antipsikotik ajanlara yanıt vermeyen olgularda önerilse de (Anderson ve ark. 2018), ileri derecede Parkinsoniyen belirtileri olan akinetik HH hastalarında ilk sırada tercih edilebilir (Bachoud-Lévi ve ark 2019). Klozapin başlanan hastaların belli aralıklarla tam kan sayımı yaptırmaları gerektiği unutulmamalı, izlem sürecine uyum sağlayabilecek hastalar klozapin tedavisine alınmalıdır. Farmakolojik tedavinin yetersiz kaldığı olgularda elektrokonvulzif tedavi bir seçenek olarak düşünülebilir (Nakano ve ark. 2013).

\section{Diğer Psikiyatrik Bozukluklar}

HH'de görülen diğer psikiyatrik bozukluklardan biri de uyku alanındaki bozukluklardır. HH'de uyku bozuklukları çok sık görülmekte, hastaların yaklaşık \%90'ı uyku bozukluğu bildirmekte, bunların da yarısı bu durumun önemli düzeyde olduğunu ifade etmektedir (Goodman ve Barker 2010). Uyku bozukluklarının henüz motor belirtiler başlamadan çok önce ortaya çıkabildiği (Goodman ve ark. 2011), diğer taraftan hastalığa ilişkin klinik belirtilerin şiddetlenmesiyle de arttığı, CAG tekrar sayısı ile ilişkisinin olmadığı bildirilmektedir (HerzogKrzywoszanska ve Krzywoszanski 2019). Uyku bozuklukları primer olabileceği gibi HH'de sık görülen diğer psikiyatrik bozuklukların (depresyon ve kaygı bozuklukları gibi) bir belirtisi de olabilir. Dolayısıyla uyku bozukluğu şikayeti ile başvuran bir $\mathrm{HH}$ hastasında, diğer psikiyatrik bozukluklar mutlaka ayırıcı tanıda ele alınmalıdır (Baker ve ark. 2016). Bunun yanı sıra özellikle de hastalığın ilerleyen evrelerinde motor hareket bozukluklarının da uykuyla ilişkili bozukluklara neden olabileceği (Neutel ve ark. 2015), bu hastalarda huzursuz bacaklar sendromunun da daha sık görülebileceği, hatta huzursuz bacaklar sendromunun diğer nöropsikiyatrik bozukluklar gibi hastalığın motor belirtileri başlamadan yıllar önce başlayabileceği bildirilmektedir (Savva ve ark. 2009). Bu nedenle uyku bozukluğu ayırıcı tanısında motor belirtilere ikincil olup olmadığı ya da hastada komorbid huzursuz bacaklar sendromu bulunup bulunmadığı da değerlendirilmelidir. Yine uykuya ilişkin şikayetlerin (uykusuzluk ya da gün içinde aşırı uykululuk gibi) mevcut ağrıya sekonder ya da kullanılan ilaçların yan etkisine bağlı olabileceği de unutulmamalıdır (Anderson ve ark. 2018).

HH'deki uykuya ilişkin belirtilerin tedavisi ile ilgili yeterli çalışmanın olmadığını söyleyebiliriz. Bu alandaki öneriler daha çok kanıt düzeyi düşük çalışmalar ve uzman görüşüne dayanmaktadır. Öncelikle her tür uyku sorunu için uyku hijyeni ile ilgili davranışsal önerilerin uygulanması gerekmektedir (Anderson ve ark. 2018). Uyku hijyeni kuralları olarak yatma zamanı ve kalkma 
zamanının belirlenmesi, gün içi kısa uyuklamalardan kaçınılması, mümkünse gün içi düzenli egzersiz yapılması, fazla miktar kafein, sigara ya da alkol kullanımından kaçınılması sayılabilir (Herzog-Krzywoszanska ve Krzywoszanski 2019). Gün içi aşırı uykululuk halinde modafinil denenebilir (Blackwell ve ark. 2008). Melatonin uykuyu kolaylaştırıcı ve sirkadiyen ritmi normalize edici etkisi ile uykusuzluk durumunda kullanılabilecek bir ajan olarak düşünülmektedir. Yine melatonin reseptör agonisterinden de (ramelteon ve agomelatin gibi) uykusuzluk durumunda fayda sağlanabilir (Herzog-Krzywoszanska ve Krzywoszanski 2019). Mirtazapin ve trazadon gibi sedasyon verici antidepresanlar da kullanılabilecek ajanlardandır. Antipsikotik olarak olanzapin ya da ketiyapin tercih edilebilir. Beraberinde obsesif kompulsif belirtileri de olan hastalar için klomipramin bir tercih olabilir. Benzodiyazepinlerin başka seçenek kalmadığı durumlar haricinde kullanılması düşme riskinden dolayı önerilmemektedir (Anderson ve ark. 2018).

HH'de görebildiğimiz bir başka psikiyatrik bozukluk da cinsel işlev bozukluklarıdır. Cinsel işlev bozuklukları sıklıkla cinsel istek azlığı ve orgazmın inhibisyonu şeklinde olsa da bazı hastalarda parafilik davranışların da gelişebildiği bildirilmektedir (Paoli ve ark. 2017). Szymus ve arkadaşlarının (2020) sistematik derlemesinde, en sik görülen cinsel bozukluklar; hipoaktif cinsel bozukluk (\%53-83), hiperaktif cinsel bozukluk (\%6-30), erektil (\%48-74) ve ejakülasyon (\%30-60) işlevinde bozukluklar, lubrikasyon sorunları (\%53-83) ve orgazm bozuklukları (\%35-78) olarak bulunmuştur. Bu alandaki bozuklukların etiyolojisinde $\mathrm{HH}$ ile ilişkili nörobiyolojik mekanizmalar olabileceği gibi, tedavide kullanılan ilaçların yan etkileri ve HH'de sık görülen nöropsikiyatrik bozuklukların (depresyon, anksiyete, apati, mani vb.) etkilerini de göz ardı etmemek gerekir. Parafililerin özellikle orgazm inhibisyonu olan ve artmış cinsel isteğe sahip erkek $\mathrm{HH}$ olgularında daha sık görüldüğüne dair bazı veriler mevcuttur (Fedoroff ve ark. 1994). Hiperseksüel davranışın erkek hastalarda daha sık görüldüğü de bildirilmektedir (Paoli ve ark. 2017, Szymus ve ark. 2020). Kolenc ve arkadaşlarının (2017) presemptomatik dönemdeki kadın mutant gen taşıyıcılarını inceledikleri çalışmalarında sağlıklı kontrollere kıyasla bu grupta cinsel işlev bozukluklarının daha sık görüldüğü ve HH'nin progresyonu ile birlikte cinsel işlev bozukluklarının arttığı saptanmıştır. İrritabilite, mental esneklik kaybı ve obsesifkompulsif ya da perseveratif davranışların hiperseksüel davranış ile ilişkili olduğu bildirilmektedir (Craufurd ve ark. 2001).

Cinsel işlev bozukluklarının tedavisi ile ilgili uzman görüşüne dayalı kılavuzlar dahi bulunmamakta, özellikle adli, sosyal, ailevi ya da toplumsal sorunlara yol açma potansiyeli olan hiperseksüel davranışların tedavisi ile ilgili vaka bildirimleri dışında kanıt bulunmamaktadır. 30 yaşında, hiperseksüel davranışların (cinsellikle ilgili konuşma ve cinsel davranışlarda belirgin artış) eşlik ettiği bir kadın HH olgusunda motor belirtiler için haloperidol kullanılmış, hiperseksüel davranışların tam geçmemesi nedeniyle tedaviye olanzapin $20 \mathrm{mg} /$ gün eklenmiş ve olanzapin ile hiperseksüel davranışların dramatik bir şekilde düzeldiği ifade edilmiştir (Jhanjee ve ark. 2011). HH’de görülebilen özellikle hiperseksüel cinsel bozukluklarının, daha çok disinhibisyon, impulsivite zemininde gelişen davranışsal sorunlar olarak değerlendirilebileceği düşünüldüğünde (Craufurd ve ark. 2001, Paoli ve ark. 2017) tedavisinde antipsikotik ajanların ön planda düşünülmesi önerilebilir. Hipoaktif cinsel bozuklukların tedavisinde cinsel tedavilere yönelik genel tedavi prensiplerinin uygulanması ve psikoeğitim en uygun müdahaleler olarak görünmektedir.

\section{Genetik Risk Altındaki Bireyler}

HH tanılı hastaların çocukları "genetik risk altındaki bireyler" olarak tanımlanabilir. Her ne kadar genetik risk altındaki bireyler ayrı bir yazının konusunu oluşturacak öneme sahipse de bu bireylerin değerlendirme süreci son derece önemli olduğundan bu yazıda da kısaca bahsetmenin gerekli olduğu düşünülmüştür.

Hastalığın otozomal dominant geçişli olduğu göz önüne alındığında $\mathrm{HH}$ tanılı bir ebeveyne sahip olmak yaklaşık \%50 ihtimalle mutant genin kalıtılması riskine işaret etmektedir (Walker 2007). Hastalığın progresif seyri ve henüz kesin tedavisi olmadığı düşünüldüğünde bu risk oldukça yüksek ve kaygı vericidir. Günümüzde genetik testler ile HH'ye ilişkin mutant gen taşıyıcılığı kolaylıkla tespit edilebilmekte ve kısa bir internet araştırması yapıldığında HH ile ilişkili genetik test yapan birçok kurumun tanıtımına rastlanabilmektedir. Oysa bu alandaki yazın profesyonel genetik danışmanlık için iyi tasarlanmış bir protokolün şart olduğu, danışmanlık verilen bireylerin intihar riskinin göz ardı edilmemesi gerektiğinin altını çizmektedir (Wahlin 2007). Mandich ve arkadaşlarının (2017) 20 yıllık izlem çalışmasında, erkeklerin kadınlara göre, > 25 yaş bireylerin 18-25 yaş aralığındaki bireylere göre daha fazla yordayıcı test yaptırma eğiliminde olduğu; çocuk sahibi olma, ilişki durumu ve $\mathrm{HH}$ olan ebeveynin cinsiyeti gibi faktörlerin kadın ve erkeklerde farklı biçimde genetik test yaptırma kararını etkilediği, çerçevesi belirli ve iyi tasarlanmış bir genetik danışmanlık protokolünün intihar gibi istenmeyen olaylar açısından güvenli olduğu saptanmıştır.

Her ne kadar erken dönem çalışmalar daha yüksek oranlara işaret etse de $\mathrm{HH}$ riski altındaki bireylerin yaklaşık \%5 gibi az bir oranının genetik test için talep ve istekte olduğu bildirilmektedir (Laccone ve ark. 1999, Walker 2007). Karabulut ve arkadaşlarının (2000) çalışmasında da, risk altındaki bireylerde yordama testine ve bunun yaşam planları üzerine etkisini konuşmaya karşı bir direnç olduğu saptanmıştır. Literatür genel olarak test yaptırma motivasyonunun altında kariyer ve aile kurma planlarının yattığını, test yaptırmayı tercih etmeyen bireylerin ise daha çok hastalığın etkin bir tedavisinin olmayışını neden olarak bildirdiklerine işaret etmektedir (Walker 2007). Genetik test protokolleri; çocuklara (<18 yaş) ve intihar fikirleri olanlara test yapılmaması gerektiğinin altını çizmektedir. Genetik test öncesi test sonuçlarının yakın aile bireyleri için (örneğin monozigot ikiz) sonuçları hakkında kapsamlı bilgilendirme yapılması, kişinin yeterli desteği olup olmadığının araştırılması ve gizlilik koşullarının kesin bir şekilde belirlenmesi gerektiği de bu protokollerde vurgulamaktadır (Tibben 2002). Tüm bu faktörler ve riskler düşünüldüğünde genetik test için danışmanlığın multidisipliner bir takım çalışması olacağı ve bu takımda 
mutlaka bir psikiyatristin ya da psikoloğun bulunması gerektiği bildirilmektedir (Groves 2017). Genetik danışmanlık hizmeti; bir ekip çalışması olarak uygulanmalı, bu ekipte genetik ve nöroloji uzmanının yanında mutlaka bir psikiyatrist ya da psikolog yer almalı, risk altındaki bireye hem genetik hem klinik açıdan yeterli bilgilendirme yapılmalı, danışman yordama testini yaptırmayı ne destekleyen ne de engelleyen bir tutum sergilemeli, tarafsız bir konum almalı, test yaptırma kararı sürecinde depresyon, umutsuzluk, kaygı, intihar eğilimi ve sosyal destek varlığı mutlaka değerlendirme dâhiline olmalıdır (Wahlin 2007).

\section{Sonuç}

$\mathrm{HH}$ her ne kadar motor belirtilerin varlığ ile klinik olarak tanı alıyor olsa da hastalığın ilk tarif edildiği zamanlardan beri nöropsikiyatrik belirtilerden de her zaman bahsedilmiş ve günümüze kadarki yazın tutarlı bir biçimde henüz motor belirtiler başlamadan yllar öncesinde nöropsikiyatrik belirti ve bozuklukların başladığını göstermiştir. HH'de nöropsikiyatrik belirtilerin, bir komorbiditeden ve hastalığa yönelik bir tepkiden çok HH'yle ilişkili nörobiyolojik alt yapının neden olduğu çekirdek belirtiler ve bozukluklar olarak değerlendirilmesi gerektiği açıktır. Genetik aktarımın yol açtığı nöropatolojik olaylar öncelikle nöropsikiyatrik belirtilere yol açmakta, ardından da motor belirtiler kendini göstermektedir. Depresyon, kayg1, intihar, obsesifkompulsif belirtiler, perseverasyonlar, irritabilite, apati, psikoz, mani, uyku bozuklukları, disinhibisyon, ajitasyon ve cinsel işlev ve davranış bozuklukları HH'de sıklıkla görebildiğimiz psikiyatrik bulgu, belirti ve bozukluklar olarak siralanabilir. Nöropsikiyatrik belirtilerin sosyal, mesleki, ailesel ve kişilerarası ilişki alanlarında işlevsellik kaybı, yașam kalitesinde azalma, bakım kurumu ve hastaneye yerleștirmelerde artma gibi olumsuz sonuçlara etkisi de motor belirtilerden daha çok görünmektedir. Bu nedenle bu belirti ve bulguların tanınması sadece hasta için değil ailesi ve bakım verenleri için de oldukça önemlidir. Tedavide güçlü kanıtlara dayalı kılavuzlardan çok daha düşük kanıt düzeyine sahip çalışmalar, vaka bildirimleri ve uzman görüşlerine dayalı protokoller bulunmaktaysa da nöropsikiyatrik belirtilerin uygun müdahaleler ile tedavisi yüz güldürücü olabilmektedir. Ancak özellikle tedavi alanında kanıt düzeyi yüksek, daha güçlü çalışmalar da ihtiyaç olduğu akılda tutulmalıdır. Mutant gen taşıyıcısı bireylerin yanında risk altındaki bireyler de ayrı bir öneme sahiptir. Bu bireyler genetik test açısından bir ekip dâhilinde değerlendirilmeli, bir psikiyatrist ya da psikolog mutlaka bu takımın içinde yer almalıdır.

Yazarlarnn Katkıları: Yazarlar çalı̧̧̧aya önemli bir bilimsel katkı sağladıklarını ve makalenin hazırlanmasında veya gözden geçirilmesinde yardımcı olduğunu kabul etmiştir.

Danışman Değerlendirmesi: Dış bağımsız.

Çıkar Çatışması: Yazarlar çıkar çatışması bildirmemiştir.

Finansal Destek: Yazarlar bu çallş̧ma için finansal destek almadığııı

beyan etmiştir.

Authors Contributions: The authors attest that she has made an important scientific contribution to the study and has assisted with the drafting or revising of the manuscript.

Peer-review: Externally peer-reviewed.

Conflict of Interest: No conflict of interest was declared by the authors.
Financial Disclosure: The authors declared that this study has received no financial support.

\section{Kaynaklar}

A'Campo LEI, Spliethoff-Kamminga NGA, Roos RAC (2012) The Patient Education Program for Huntington's Disease (PEP-HD). J Huntingtons Dis, 1:47-56.

Adrissi J, Nadkarni NA, Gausche E, Bega D (2019) Electroconvulsive therapy (ECT) for refractory psychiatric symptoms in Huntington's disease: a case series and review of the literature. J Huntingtons Dis, 8:291-300.

Anderson KE (2005) Huntington's disease, and related disorders. Psychiatr Clin North Am, 28:275-290.

Anderson KE, van Duijn E, Craufurd D, Drazinic C, Edmondson M, Goodman $\mathrm{N}$ et al. (2018). Clinical management of neuropsychiatric symptoms of huntington disease: expert-based consensus guidelines on agitation, anxiety, apathy, psychosis and sleep disorders. J Huntingtons Dis, 7:355-366.

Anderson KE, Eberly S, Groves M, Kayson E, Marder K, Young AB et al. (2016) Risk factors for suicidal ideation in people at risk for Huntington's disease. J Huntingtons Dis, 5:389-394.

Arran N, Craufurd D, Simpson J (2014) Illness perceptions, coping styles and psychological distress in adults with Huntington's disease. Psychol Health Med, 19:169-179.

Ataöv G, Akbaş I, Gül O, Balaban OD, Tanrıverdi Seda (2020) Psikiyatri servisinde Huntington Hastalığı vakas1. 5. Psikiyatri Zirvesi ve 12. Anksiyete Kongresi, 29-31 Ekim Antalya, Türkiye. Kongre Özet Kitabı pp: 272.

Bachoud-Lévi AC, Ferreira J, Massart R, Youssov K, Rosser A, Busse M et al. (2019). International guidelines for the treatment of Huntington's disease. Front Neurol, 10:710.

Baker CR, Domínguez D JF, Stout JC, Gabery S, Churchyard A, Chua P et al. (2016) Subjective sleep problems in Huntington's disease: a pilot investigation of the relationship to brain structure, neurocognitive, and neuropsychiatric function. J Neurol Sci, 364:148-153.

Bayram E, Mercan FN, Akbostancı MC (2015) Uneventful recovery from a suicide attempt with tetrabenazine: a case report. Turk J Neurol, 21:175176

Beglinger LJ, Paulsen JS, Watson DB, Wang MC, Duff K, Langbehn DR et al. \& PREDICT-HD Investigators of the Huntington Study Group (2008) Obsessive and compulsive symptoms in prediagnosed Huntington's disease. J Clin Psychiatry, 69:1758-1765.

Bhattacharyya KB (2016). The story of George Huntington and his disease. Ann Indian Acad Neurol, 19:25-28.

Blackwell AD, Paterson NS, Barker RA, Robbins TW, Sahakian BJ (2008) The effects of modafinil on mood and cognition in Huntington's disease. Psychopharmacology, 199:29-36.

Boyle A, Malloy PF, Salloway S, Cahn-Weiner DA, Cohen R, Cummings JL (2003) Executive dysfunction and apathy predict functional impairment in Alzheimer disease. Am J Geriatr Psychiatry, 11:214-221.

Camacho M, Barker RA, Mason SL (2018) Apathy in Huntington's Disease: A review of the current conceptualization. J Alzheimers Dis Parkinsonism, $8: 431$

Chatterjee A, Anderson KE, Moskowitz CB, Hauser WA, Marder KS (2005) A comparison of self-report and caregiver assessment of depression, apathy, and irritability in Huntington's disease. J Neuropsychiatry Clin Neurosci, $17: 378-383$

Chu EMY, O’Neill M, Purkayastha DD, Knight C (2019) Huntington's disease: a forensic risk factor in women. J Clin Mov Disord, 6:3.

Connors MH, Teixeira-Pinto A, Loy CT (2020) Psychosis and longitudinal 
outcomes in Huntington disease: the COHORT Study. Neural Neurosourg Psychiarty, 91:15-20.

Craig KJ, Hietanen H, Markova IS, Berrios GE (2008) The Irritability Questionnaire: A new scale for the measurement of irritability. Psychiatry Res, 159:367-375.

Craufurd D, Thompson JC, Snowden JS (2001) Behavioral changes in Huntington disease. Neuropsychiatry Neuropsychol Behav Neurol, 14:219226.

Craufurd D, Snowden J (2002) Neuropsychological and neuropsychiatric aspects of Huntington's disease. In: Huntington's disease (Eds G Bates, $P$ Harper, L Jones):62-94. New York, NY, Oxford University Press.

Dale M, van Duijn E (2015) Anxiety in Huntington's disease. J Neuropsychiatry Clin Neurosci, 27:262-271.

Danivas V, Moily NS, Thimmaiah R, Muralidharan K, Purushotham M, Muthane U et al. (2013) Off label use of lithium in the treatment of Huntington's disease: A case series. Indian J Psychiatry, 55:81-83.

Duff K, Paulsen JS, Beglinger LJ, Langbehn DR, Stout JC (2007) PredictHD Investigators of the Huntington Study Group: Psychiatric symptoms in Huntington's disease before diagnosis: the predict-HD study. Biol Psychiatry, 62:1341-1346

Eddy CM, Parkinson EG, Rickards HE (2016) Changes in mental state and behaviour in Huntington's disease. Lancet Psychiatry, 3:1079-1086.

Fedoroff JP, Peyser, C, Franz ML, Folstein SE (1994) Sexual disorders in Huntington's disease. J Neuropsychiatry Clin Neurosci, 6:147-153.

Fiedorowicz JG, Mills JA, Ruggle A, Langbehn D, Paulsen JS (2011) PREDICT-HD Investigators of the Huntington Study Group Suicidal behavior in prodromal Huntington disease. Neurodegener Dis, 8:483-490.

Gibson JS, Rhoten BA, Ridner SH, Claassen DO (2022) Perceived effects of neuropsychiatric symptoms on functional status in early-stage Huntington disease. West J Nurs Res, 44:141-150.

Goh AM, Wibawa P, Loi SM, Walterfang M, Velakoulis D, Looi JC (2018). Huntington's disease: neuropsychiatric manifestations of Huntington's disease. Australas Psychiatry, 26:366-375

Goodman AOG, Barker RA (2010) How vital is sleep in Huntington's disease? J Neurol, 257:882-987.

Goodman AOG, Rogers L, Pilsworth S, McAllister CJ, Shneerson JM, Morton AJ et al. (2011) Asymptomatic sleep abnormalities are a common early feature in patients with Huntington's disease. Curr Neurol Neurosci Rep, 11:211-217.

Groves M, van Duijn E, Anderson K, Craufurd D, Edmondson MC, Goodman N et al. (2011) An international survey-based algorithm for the pharmacologic treatment of irritability in Huntington's disease. PLoS Curr, 3:RRN1259.

Groves M (2017) The highly anxious individual presenting for Huntington disease-predictive genetic testing: the psychiatrist's role in assessment and counseling. In Handbook of Clinical Neurology (Eds AS Feign, KE Anderson): 99-105. Cambridge, MA, Elsevier.

Gubert C, Renoir T, Hannan AJ (2020) Why Woody got the blues: The neurobiology of depression in Huntington's disease. Neurobiol Dis, 142:104958.

Harris KL, Kuan WL, Mason SL, Barker RA (2020) Antidopaminergic treatment is associated with reduced chorea and irritability but impaired cognition in Huntington's disease (Enroll-HD). J Neurol Neurosurg Psychiatry, 91:622-630.

Herzog-Krzywoszanska R, Krzywoszanski L (2019) Sleep disorders in Huntington's disease. Front Psychiatr, 10:221.
Honrath P, Dogan I, Wudarczyk O, Görlich KS, Votinov M, Werner CJ et al. (2018) Risk factors of suicidal ideation in Huntington's disease: literatüre review and data from Enroll-HD. J Neurol 265:2548-2561.

Hubers AA, van Duijn E, Roos R, Craufurd D, Rickards H, Landwehrmeyer GB et al. (2013) Suicidal ideation in a European Huntington's Disease Population. J Affect Disord, 151:248-258.

Huntington G (1872) On chorea. The Medical and Surgical Reporter, 26(15):317-321.

Ishihara L, Oliveri D, Wild EJ (2021) Neuropsychiatric comorbidities in Huntington's and Parkinson's Disease: A United States claims database analysis. Ann Clin Transl Neurol, 8:126-137.

Jaini A, Yomtoob J, Yeh C, Bega D (2020) Understanding HD psychosis: an analysis from the ENROLL-HD Database. Tremor Other Hyperkinet Mov, 10:16.

Jhanjee A, Anand KS, Bajaj BK (2011). Hypersexual features in Huntington's. Singapore Med J, 52:131-133.

Kachian ZR, Cohen-Zimerman S, Bega D, Gordon B, Grafman J (2019) Suicidal ideation and behavior in Huntington's disease: systematic review and recommendations. J Affect Disord, 250:319-329.

Kar SK, Shahi MK, Tripathi A, Sharma PK (2017). Predicting prognosis of psychosis in Huntington's disease: Case report and review of literature. J Neurosci Rural Pract, 8:469-471.

Karabulut HG, Akbostancı C, Atbaşoğlu C, Bökesoy I, Mutluer N (2000) Predictive testing in Huntington's Disease: neurologic, genetic and psychiatric evaluation. Parkinson Hastalığı ve Hareket Bozuklukları Dergisi, 3:7-12.

Karagas NE, Rocha NP, Stimming EF (2020). Irritability in Huntington's disease. J Huntingtons Dis, 9:107-113.

Kirkwood SC, Siemers E, Viken R, Hodes ME, Conneally PM, Christian JC et al. (2002) Longitudinal personality changes among presymptomatic Huntington disease gene carriers. Cogn Behav Neurol, 15:192-197.

Kolenc M, Kobal J, Podnar S (2017) Female sexual dysfunction in presymptomatic mutation carriers and patients with Huntington's Disease. J Huntingtons Dis, 6:105-113.

Laccone F, Engel U, Holinski-Feder E, Weigell-Weber M, Marczinek K, Nolte $D$ et al. (1999) DNA analysis of Huntington's disease: five years of experience in Germany, Austria, and Switzerland. Neurology, 53:801-806.

Levy ML, Cummings JL, Fairbanks LA, Masterman D, Miller BL, Craig AH et al. (1998) Apathy is not depression. J Neuropsychiatry Clin Neurosci, 10:314-319.

Loi SM, Walterfang M, Velakoulis D, Looi JC (2018) Huntington's disease: Managing neuropsychiatric symptoms in Huntington's disease. Australas Psychiatry, 26:376-380.

Mandich P, Lamp M, Gotta F, Gulli R, Iacometti A, Marchese R et al. (2017). 1993-2014: two decades of predictive testing for Huntington's disease at the Medical Genetics Unit of the University of Genoa. Mol Genet Genomic Med, 5:473-480.

Marshall J, White K, Weaver M, Wetherill LF, Hui S, Stout JC et al. (2007). Specific psychiatric manifestations among preclinical Huntington disease mutation carriers. Arch Neurol, 64:116-121.

Martinez-Horta S, Perez-Perez J, van Duijn E, Fernandez-Bobadilla R, Carceller M, Pagonabarraga J et al. (2016). Neuropsychiatric symptoms are very common in premanifest and early stage Huntington's disease. Parkinsonism Relat Disord, 25:58-64.

Morris M (1991) Psychiatric aspects of Huntington's disease. In Huntington's Disease,(Ed. PS Harper):81-126. London, UK, WB Saunders.

Nakano T, Ono S, Yamaguchi J, Sugimoto R, Yamaguchi N, Morimoto Y et al. 
(2013) Modified electroconvulsive therapy for the treatment of refractory schizophrenia-like psychosis associated with Huntington's disease. J Neurol, 260:312-314

Nance M, Paulsen JS, Rosenblatt A, Wheelock V (2011) A Physician's Guide to the Management of Huntington's Disease. United States, Huntington's Disease Society of America.

Neutel D, Tchikviladzé M, Charles P, Leu-Semenescu S, Roze E, Durr A et al. (2015) Nocturnal agitation in Huntington disease is caused by arousalrelated abnormal movements rather than by rapid eye movement sleep behavior disorder. Sleep Med, 16:754-759.

Nimmagadda SR, Agrawal N, Worrall-Davies A, Markova I, Rickards H (2011) Determinants of irritability in Huntington's disease. Acta Neuropsychiatr, 23:309-314

Nock MK, Borges G, Bromet EJ, Alonso J, Angermeyer M, Beautrais A et al. (2008) Cross-national prevalence and risk factors for suicidal ideation, plans and attempts. Br J Psychiatry, 192:98-105.

Oosterloo M, Craufurd D, Nijsten H, van Duijn E (2019) Obsessivecompulsive and perseverative behaviors in Huntington's disease. J Huntingtons Dis, 8:1-7.

Paoli RA, Botturi A, Ciammola A, Silani V, Prunas C, Lucchiari C et al. (2017) Neuropsychiatric burden in Huntington's disease. Brain Sci,7:67.

Paulsen JS (2009) Functional imaging in Huntington's disease. Exp Neurol, 216:272-77.

Paulsen JS, Ready RE, Hamilton JM, Mega MS, Cummings JL (2001) Neuropsychiatric aspects of Huntington's disease. J Neurol Neurosurg Psychiatry, 71:310-314.

Paulsen JS, Miller AC, Hayes T, Shaw E (2017) Cognitive and behavioral changes in Huntington disease before diagnosis. In: Handbook of Clinical Neurology. Elsevier, pp. 69-91.

Paulsen JS, Hoth KF, Nehl C, Stierman L, The Huntington Study Group (2005) Critical periods of suicide risk in Huntington's disease. Am J Psychiatry 162:725-731.

Ratna N, Kamble NL, Venkatesh SD, Purushottam M, Pal PK, Jain S (2020) Psychiatric morbidity and poor follow-up underlie suboptimal functional and survival outcomes in Huntington's disease. BMC Neurol, 20:87.

Rawlins M (2010) Huntington's disease out of the closet? Lancet, 376:13721373.

Ready RE, Matthews M, Leserman A, Paulsen JS (2008) Patient and caregiver quality of life in Huntington's disease. Mov Disord, 23:721-726.

Reedeker W, van der Mast RC, Giltay EJ, Kooistra TA, Roos RA, van Duijn E (2012a) Psychiatric disorders in Huntington's disease: A 2-year follow-up study. Psychosomatics, 53:220-229.

Reedeker N, Bouwens JA, Giltay EJ, Le Mair SE, Roos RA, van der Mast RC et al. (2012b). Irritability in Huntington's disease. Psychiatry Res, 200:813818.

Rodrigues FB, Abreu D, Damásio J, Goncalves N, Correia-Guedes L, Coelho M et al. (2017) Survival, mortality, causes and places of death in a European Huntington's disease prospective cohort. Mov Disord Clin Pract, 4:737-742.

Ross CA, Tabrizi SJ (2011) Huntington's disease: from molecular pathogenesis to clinical treatment. Lancet Neurol, 10:83-98.

Ross CA, Aylward EH, Wild EJ (2014) Huntington disease: natural history, biomarkers and prospects for therapeutics. Nat Rev Neurol, 10:204-216.

Rossi G, Oh JC (2020) Management of agitation in huntington's disease: a review of the literature. Cureus,12:e9748.

Salman S, Balaban OD, Erten E, Karamustafalioglu N (2018) İlk başvurusu psikiyatrik belirtilerle olan bir Huntington Hastalığı olgusu. 3. Psikiyatri
Zirvesi ve 10. Anksiyete Kongresi, 15-18 Mart 2018 Antalya, Türkiye. Kongre Özet Kitabı sayfa: 249-250.

Savva E, Schnorf H, Burkhard PR (2009) Restless legs syndrome: an early manifestation of Huntington's disease? Acta Neurol Scand, 119:274-276.

Scheuing L, Chiu CT, Liao HM, Linares GR, Chuang DM (2014) Preclinical and clinical investigations of mood stabilizers for Huntington's disease: what have we learned? Int J Biol Sci, 10:1024-1038.

Serpell L, Waller G, Fearon P, Meyer C (2009) The roles of persistence and perseveration in psychopathology. Behav Ther, 40:260-271.

Sexton A, West K, Gill G, Wiseman A, Taylor J, Purvis R et al. (2021) Suicide in frontotemporal dementia and Huntington disease: analysis of family-reported pedigree data and implications for genetic healthcare for asymptomatic relatives. Psychol Health, 36:1397-1402.

Silver A (2003) Cognitive-behavioural therapy with a Huntington's gene positive patient. Patient Educ Couns, 49:133-138.

Sinanović O (2020) Psychiatric disorders in neurological diseases. In Mind and Brain: Bridging Neurology and Psychiatry, (Ed V Demarin): 65-79 Cham, Switzerland, Springer.

Slaughter JR, Martens M.P, Slaughter KA (2001) Depression and Huntington's disease: Prevalence, clinical manifestations, aetiology, and treatment. CNS Spectr, 6:306-326.

Solberg OK, Filkuková P, Frich JC, Feragen KJB (2018) Age at death and causes of death in patients with Huntington Disease in Norway in 19862015. J Huntingtons Dis, 7:77-86.

Squitieri F, Cannella M, Porcellini A, Brusa L, Simonelli M, Ruggieri S (2001) Short-term effects of olanzapine in Huntington disease. Neuropsychiatry Neuropsychol Behav Neurol, 14:69-72.

Stahl CM, Feigin A (2020) Medical, surgical, and genetic treatment of Huntington Disease. Neurol Clin, 38:367-378.

Stober T, Wussow W, Schimrigk K (1984) Bicaudate diameter: the most specifi c and simple CT parameter in the diagnosis of Huntington's disease. Neuroradiology, 26:25-28.

Strassburger K, Andrich J, Saft C (2008) Bupropion: first experience in Huntington's Disease. J Neurol Neurosurg Psychiatry, 79:29-30.

Szymuś K, Bystrzyński A, Kwaśniak-Butowska M, Konkel A, Leśnicka A, Nowacka M et al. (2020). Sexual dysfunction in Huntington's Disease-a systematic review. Neurol Neurochir Pol, 54:305-311.

Thompson JC, Harris J, Sollom AC, Stopford CL, Howard E, Snowden JS et al. (2012) Longitudinal evaluation of neuropsychiatric symptoms in Huntington's disease J Neuropsychiatry Clin Neurosci, 24:53-60.

Tibben A (2002) Genetic counseling and presymptomatic testing. In Huntington's Disease (Eds G Bates, P Harper, L Jones):198-250. New York, Oxford University Press.

Tsuang D, Almqvist EW, Lipe H, Strgar F, DiGiacomo L, Hoff D et al. (2000) Familial aggregation of psychotic symptoms in Huntington's disease. Am J Psychiatry, 157:1955-1959.

Vamos M, Hambridge J, Edwards M, Conaghan J (2007) The impact of Huntington'sdisease on family life. Psychosomatics, 48:400-404.

van der Meer L, van Duijn E, Wolterbeek R, Tibben A (2014) Offspring of a parent with genetic disease: childhood experiences and adult psychological characteristics. Health Psychol, 33:1445-1453.

van Duijn E, Kingma EM, van der Mast RC (2007) Psychopathology in verified Huntington's disease gene carriers. J Neuropsychiatry Clin Neurosci, 19:441-448. 
van Duijn E, Kingma EM, Timman R, Zitman FG, Tibben A, Roos RAC et al. (2008) Cross-sectional study on prevalences of psychiatric disorders in mutation carriers of Huntington's disease compared with mutationnegative firstdegree relatives. J Clin Psychiatry, 69:1804-1810.

van Duijn E, Reedeker N, Giltay EJ, Roos RAC, van der Mast RC (2010) Correlates of apathy in Huntington's disease. J Neuropsychiatry Clin Neurosci, 22:287-294.

van Duijn E, Craufurd D, Hubers AA, Giltay EJ, Bonelli R, Rickards H et al. for the European Huntington's Disease Network Behavioural Phenotype Working Group (2014) Neuropsychiatric symptoms in a European Huntington's disease cohort (REGISTRY). J Neurol Neurosurg Psychiatry, 85:1411-1418.

van Duijn E, Vrijmoeth EM, Giltay EJ, Bernhard F, Landwehrmeyer G, REGISTRY investigators of the European Huntington's Disease Network (2018) Suicidal ideation and suicidal behavior according to the C-SSRS in a European cohort of Huntington's disease gene expansion carriers. J Affect Disord, 228:194-204.
Wahlin TBR (2007). To know or not to know: a review of behaviour and suicidal ideation in preclinical Huntington's disease. Patient Educ Couns, 65:279-287.

Walker FO (2007) Huntington's disease. Lancet, 369:218-228.

Wesson M, Boileau NR, Perlmutter JS, Paulsen JS, Barton SK, McCormack MKet al. (2018) Suicidal ideation assessment in individuals with premanifest and manifest Huntington Disease. J Huntingtons Dis, 7:239-249.

Wetzel HH, Gehl CR, Dellefave-Castillo L, Schiffman JF, Shannon KM, Paulsen JS (2011) Huntington Study Group: Suicidal ideation in Huntington disease: the role of comorbidity. Psychiatry Res, 188:372-376.

Wolf RC, Vasic N, Schönfeldt-Lecuona C, Ecker D, Landwehrmeyer GB (2008). Functional imaging of cognitive processes in Huntington's disease and its presymptomatic mutation carriers. Der Nervenarzt, 79:408-420. 